\title{
A re-examination of the mechanism of whiting events: A new role for diatoms in Fayetteville Green Lake (New York, USA)
}

3 Short running title: Re-examining whiting events in Fayetteville Green Lake

4 Authors and affiliations:

5 Chloe Stanton ${ }^{1}$, Julie Cosmidis ${ }^{1,2, *}$, and Lee R. Kump ${ }^{1,2}$

6 1 Department of Geosciences, The Pennsylvania State University, University Park, PA 16802, 7 USA

8 2Earth and Environmental Systems Institute, The Pennsylvania State University, University Park, 9 PA 16802, USA

$10 *$ Current address: Department of Earth Sciences, University of Oxford, Oxford OX1 03N, UK

\section{Correspondence:}

13 Julie Cosmidis, Department of Earth Sciences, University of Oxford, Oxford OX1 03N, UK.

14 Email: Julie.comidis@ earth.oc.ac.uk.

15 Twitter : @ JCosmidis

Key words:

Whitings, biomineralization, diatoms, calcite, micrite, ACC 


\section{ABSTRACT}

24 Whiting events - the episodic precipitation of fine-grained suspended calcium cabonates

25 in the water column - have been documented across a variety of marine and lacustrine

26 environments. Whitings likely are a major source of carbonate muds, a constituent of limestones,

27 and important archives for geochemical proxies of Earth history. While several biological and

28 physical mechanisms have been proposed to explain the onset of these precipitation events, no

29 consensus has been reached thus far. Fayetteville Green Lake (New York, USA), is a meromictic

30 lake that experiences annual whitings. Materials suspended in the water column collected through

31 the whiting season were characterized using scanning electron microscopy and scanning

32 transmission X-ray microscopy. Whitings in Fayetteville Green Lake are initiated in the spring

33 within the top few meters of the water column, by precipitation of fine amorphous calcium

34 carbonate (ACC) phases nucleating on Synechococcus cells (cyanobacteria), as well as on

35 extracellular polymeric substances (EPS), including abundant $\beta$-chitin fibrils exuded by centric

36 diatoms. Whiting particles found in the summer consist of 5-7 $\mu \mathrm{m}$ calcite grains forming

37 aggregates with diatoms and their EPS. Simple calculations demonstrate that calcite particles

38 continuously grow over several days, then sink quickly through the water column. In the late

39 summer, partial calcium carbonate dissolution is observed deeper in the water column. Settling

40 whiting particles however reach the bottom of the lake, where they form a major constituent of the

41 sediment, along with diatom frustules. The importance of diatoms and their EPS in whitings at

42 Fayetteville Green Lake is described for the first time here, a largely overlooked mechanism for 43 other whiting events in modern and ancient environments. 


\section{INTRODUCTION}

Fine-grained (micritic) limestone is abundant in the sedimentary record and an important

46 repository for geochemical and isotopic proxy records of Earth history. Despite its importance, the

47 origin of marine mud has been a topic of considerable uncertainty and research for decades

48 (Bathurst, 1966), with both inorganic and biogenic mechanisms being proposed. One source of

49 mud, the apparently spontaneous precipitation of very fine suspended calcium carbonate $\left(\mathrm{CaCO}_{3}\right)$

50 particles, called a whiting, has been observed to occur and persist for many days in marine

51 environments, most notably in the Bahamas (Broecker \& Takahashi, 1966; Shinn et al., 1989;

52 Robbins et al., 1997; Purkis et al., 2017). Physical disturbance and re-suspension of carbonate

53 sediments (e.g., Boss \& Neumann, 1993; Broecker et al., 2000; Morse et al., 2003; Dierssen et al.,

54 2009; Broecker, 2012), chemical precipitation (Brunskill, 1969), and biological mediation (e.g.,

55 Robbins \& Blackwelder, 1992; Thompson, 2000; Swart et al., 2014; Long et al., 2017) have been

56 proposed to explain the whiting phenomenon.

\subsection{Biological hypotheses for the origin of whitings}

cyanobacteria) has often been invoked for whiting production, supported by the fact that whiting

60 events often coincide spatially and temporally with high abundances of these organisms (Schultze-

61 Lam et al., 1997; Hodell et al., 1998; Thompson, 2000; Dittrich et al., 2004; Dittrich \& Obst,

62 2004). Biological models for the onset of whitings frequently involve the heterogeneous nucleation

63 of $\mathrm{CaCO}_{3}$ minerals on microbial surfaces and extracellular organic materials in supersaturated

64 waters (Robbins \& Blackwelder, 1992; Schultze-Lam et al., 1992; Thompson, 2000).

65 Picocyanobacteria in particular, because of their small sizes, offer a larger surface area for $\mathrm{CaCO}_{3}$ 
66 nucleation (Robbins \& Blackwelder, 1992; Hodell et al., 1998; Dittrich et al., 2004; Dittrich \&

67 Obst, 2004). Some studies have focused more specifically on the role of the S-layer of

68 picocyanobacteria of the genus Synechococcus. Forming a hexagonally symmetric paracrystalline

69 surface array, the S-layer may act as a template favoring calcite nucleation at the cell surface

70 (Thompson \& Ferris, 1990; Schultze-Lam et al., 1992, 1997; Thompson, 2000).

71 In addition to models based on $\mathrm{CaCO}_{3}$ nucleation on microbial surfaces ("passive"

72 mineralization), cyanobacteria and other photosynthetic organisms might also provoke whiting

73 events by locally increasing supersaturation with respect to calcium carbonates though $\mathrm{CO}_{2}$ uptake

74 ("active" mineralization) (Schultze-Lam et al., 1997; Thompson, 2000; Dittrich \& Obst, 2004).

75 Recently, Lisle \& Robbins (2016) hypothesized that viral lysis of cyanobacterial cells releases

76 cytoplasmic bicarbonate - which is 23 times more concentrated in the cytoplasm than in seawater

77 - leading to extreme mineral supersaturation in the immediate vicinity of the cells, and enabling

78 homogeneous nucleation of $\mathrm{CaCO}_{3}$.

79 Other mechanisms for microbial precipitation of $\mathrm{CaCO}_{3}$ minerals have been described in

80 the literature dealing with calcifying microbial mats and microbialites (e.g., Dupraz \& Visscher,

81 2005; Dupraz et al., 2009; Zhu \& Dittrich, 2016). Some of these mechanisms, such as bacterial

82 sulfate reduction or anoxygenic photosynthesis, are irrelevant to whiting events, which occur in

83 the oxygenated photic zone of the water column. Others, such as the degradation of microbial EPS

84 locally releasing calcium and carbonate ions, could be relevant to planktonic $\mathrm{CaCO}_{3}$ formation,

85 but it is not clear whether such mechanisms could be playing a role in the onset of whitings. Finally,

86 some cyanobacteria (Benzerara et al., 2014) as well as other bacterial types (Benzerara et al., 2021;

87 Monteil et al., 2021) and microalgae (Martignier et al., 2017) can form amorphous intracellular 
88 calcium carbonate biominerals, but their involvement in whiting events has never been 89 documented.

\subsection{A role of diatoms in whitings?}

Several studies have described an association of planktonic and benthic $\mathrm{CaCO}_{3}$

92 precipitation with diatom species in different marine and lacustrine environments (Winsborough

93 \& Golubić, 1987; Küchler-Krischun \& Kleiner, 1990; Winsborough, 2000; Ehrlich et al., 2016;

94 Fuchs et al., 2016; Long et al., 2017; Gomez et al., 2018). Diatoms can produce large amounts of 95 extracellular polymeric substances (EPS), also called mucilage, playing different roles such as 96 adhesion, motility, protection, and heavy metals detoxification (Urbani et al., 2012; Shnyukova \&

97 Zolotareva, 2015). In oligotrophic hardwater lakes, diatoms have been observed in increasing 98 numbers, causing ecological strain (Kirkwood et al., 2007; Novis et al., 2017), and their abundance 99 sometimes coincides with increased sedimentation of $\mathrm{CaCO}_{3}$ (Stabel, 1986; Fuchs et al., 2016). In 100 at least one marine environment (southwest Florida), $\mathrm{CaCO}_{3}$ whiting particles where associated 101 with centric diatoms (Long et al., 2017), but it is unclear whether diatoms or their EPS could be a 102 significant factor in calcium carbonate nucleation in other modern whiting events.

\subsection{Whiting events at Fayetteville Green Lake}

104

Fayetteville Green Lake (FGL) (NY, United States) is a $53 \mathrm{~m}$ deep, permanently stratified

105 lake where annual whitings have been documented. The lake redoxcline at $\sim 20 \mathrm{~m}$ water depth 106 separates an upper, wind-mixed, oxygenated mixolimnion from a lower, slightly denser, euxinic 107 monimolimnion (Takahashi et al., 1968). The surface waters of FGL are supersaturated with 108 respect to calcite $(\Omega \approx 10)$ (Takahashi et al., 1968), and experience a whiting every spring, when 
109 precipitation of fine-grained suspended calcite transforms the lake color from deep blue to 110 turquoise (Thompson et al., 1990; Schultze-Lam et al., 1997).

111 Previous investigations of FGL documented the evolution of the whiting over time 112 (Schultze-Lam et al., 1997), and showed that the initiation of the whiting in the spring (May)

113 roughly coincides with an annual cyanobacterial bloom. Carbon stable isotope measurements in 114 the water column and the sediment of the lake further suggest that photosynthesis-driven carbonate 115 precipitation in the mixolimnion is the primary source of carbonate minerals in the sediments 116 (Schultze-Lam et al., 1997; Havig et al., 2017). A model for the onset on the whiting has been 117 proposed in the 1990s, in which Synechococcus (micron-sized coccoid cyanobacteria) were the 118 main biological agents driving $\mathrm{CaCO}_{3}$ precipitation. The cyanobacteria are thought to be driving 119 local increases of saturation state from their photosynthetic activity, and acting as sites for mineral 120 nucleation (Thompson et al., 1990; Schultze-Lam et al., 1997). A Synechococcus strain isolated 121 from FGL was shown in the laboratory to nucleate calcite crystals at the cell surface, possibly 122 templated on the S-layer (Thompson \& Ferris, 1990; Schultze-Lam et al., 1992). Recently, 123 Kamennaya et al. (2020) have shown that Synechococcus thriving in the surface waters of FGL 124 produce abundant EPS that can adsorb diverse cations (including calcium) and detach from the 125 cells. However, it is not clear whether or not these cell-free calcium-loaded EPS envelopes play a 126 role in triggering whitings at FGL.

127 Other recent studies on FGL have focused on thrombolitic microbialites growing on the 128 lake shore (DeMott et al., 2020), isotopic fractionation effects associated with microbial calcite 129 precipitation (Chen et al., 2021), as well as carbon and nitrogen biogeochemical cycling (Havig et 130 al., 2017; Fulton et al., 2018), sulfur biogeochemistry (Zerkle et al., 2010; Oduro et al., 2013), and 
131 microbial and geochemical processes at the chemocline and in the monimolimnion (Meyer et al., 132 2011; Hunter, 2012; Havig et al., 2015; Rojas et al., 2021).

133 We performed a high-resolution microscopy and spectroscopy characterization of particles 134 suspended in the water column of FGL and collected through the whiting season, as well as of 135 particles from the lake bottom sediments, enabling us to propose new hypotheses for the biological 136 mechanisms involved in whiting events and carbonate sedimentation. Park, in Fayetteville, NY (United States). Five field trips were executed on April 16, May 31, June 141 30, August 1, and September 8 of 2018. Samples were collected from a boat stationed near the 142 lake center. Water samples were collected using a peristaltic pump at every $1 \mathrm{~m}$ interval for the 143 top $\sim 10 \mathrm{~m}$ of the water column. Both filtered $(0.2 \mu \mathrm{m}$ polycarbonate filters $)$ and unfiltered water 144 samples were collected and stored at $4^{\circ} \mathrm{C}$. Polycarbonate filters were immediately rinsed with 145 deionized (DI) water, air-dried, and stored for later microscopy analyses. Sediment trap samples 146 analyzed in this study were collected by S. Romaniello (University of Tennessee, Knoxville)

147 between July 12 and July 21,2017 from 13.5 depth, and stored at $-20^{\circ} \mathrm{C}$ prior to analyses. Samples 148 from the top 4 inches of a Green Lake bottom sediment core were also analyzed. These sediment 149 core samples were freeze-dried for preservation. They have been further described elsewhere 150 (Havig et al., 2015, 2017). 
Suspended particles from the water column and collected on polycarbonate filters, as well

153 as rinsed sediment trap samples, were characterized using scanning electron microscopy (SEM)

154 on a FEI Nova NanoSEM 630 field emission gun SEM. Elemental information was derived from

155 Energy-dispersive X-ray Spectroscopy (EDS) (Oxford Instruments UltimMax detector) to confirm

156 the mineralogy of observed particles. Images were collected at accelerating voltages ranging from

$157 \quad 5-15 \mathrm{keV}$ and at working distances down to $3 \mathrm{~mm}$, while EDS analyses were conducted at $15 \mathrm{keV}$

158 at working distances down to $7 \mathrm{~mm}$. EDS data was processed using the program Oxford Aztec.

159 Mineral morphology and texture, size, and abundances, as well as diatom abundances were

160 assessed using SEM images generated throughout the whiting season by manual counting on $\sim 700$

$161 \mu \mathrm{m} \times 700 \mu \mathrm{m}$ SEM images of the filters. Three types of particles were counted and measured on

162 these large-scale overview images: pennate diatoms, centric diatoms, and carbonate grains. The

163 visual aspect of the carbonate particles was furthermore characterized as either intact or pitted (as

164 indicative of dissolution). Once all particles on these larger images had been counted, the

165 volumetric concentrations of each type of particle was calculated, using the volume of filtered

166 water for each filter and filter area. The areas counted $\left(\sim 0.49 \mathrm{~mm}^{2}\right)$ were assumed to be

167 representative of the entire filters $\left(\sim 490 \mathrm{~mm}^{2}\right)$, which contained all particles from the originally

168 filtered $60 \mathrm{~mL}$ samples. Using these values, particle counts from the SEM images were converted 169 into concentrations of particles per milliliter.

\section{$170 \quad$ 2.3 Scanning Transmission X-ray Microscopy (STXM)}

$171 \quad$ 2.3.1 STXM data acquisition and processing 
173 on the sub-micrometer scale distribution and speciation of carbon and calcium in minerals and

174 associated organics. STXM analyses were performed on beamline SM at the Canadian Light 175 Source, Saskatoon, SK, operating with a $35 \mathrm{~nm}$ zone plate (ZP) on samples collected from the 176 water column in April 2018. Another beamtime at the STXM beamline 5.3.2.2 (operating with a $17725 \mathrm{~nm}$ ZP) of the Advance Light Source, Berkeley National Lab, CA, was used to analyze sediment 178 trap and sediment core samples. For STXM, particulate materials were centrifuged, rinsed with 179 deionized water, and deposited onto silicon nitride windows (Norcada).

181 (Hitchcock, 2012). Transmission images were first converted to optical density (OD). At the C K182 edge, organic carbon maps were generated by subtracting an OD image at $280 \mathrm{eV}$ (below the C K183 edge) from another at $288.2 \mathrm{eV}$ (absorption energy of $1 \mathrm{~s} \rightarrow \pi^{*} \mathrm{C}=\mathrm{O}$ electronic transitions in amide 184 groups). Calcium maps were obtained at the $\mathrm{Ca} \mathrm{L}_{2,3}$-edge by subtracting an OD image at $343 \mathrm{eV}$ 185 (below the $\mathrm{Ca} \mathrm{L}_{3}$-edge) from another at $349.3 \mathrm{eV}$ (energy of the $\mathrm{Ca} \mathrm{L}_{3}$-edge).

186 X-ray absorption near edge structure (XANES) spectra were extracted from image stacks 187 according to the procedure described by Cosmidis \& Benzerara (2014). The Stack Fit tool of 188 aXis2000 was used to extract and map the distribution of representative components in image 189 stacks. Linear background removal was performed on XANES spectra in the 270-283 eV energy 190 range below the $\mathrm{C}$ K-edge and the 340-346 eV energy range below the Ca $\mathrm{L}_{2,3}$-edge.

\subsubsection{Determination of $I_{C} / I_{C a}$ ratios}

XANES spectra at the $\mathrm{C} \mathrm{K}$-edge and $\mathrm{Ca}_{2,3}$-edge were used to obtain a semi-quantitative

193 measure of elemental ratios of carbon versus calcium in the samples. The $I_{C} / I c_{a}$ ratio is defined as 194 the ratio of the areas under the spectra in the $280-310 \mathrm{eV}$ region versus the $345-354 \mathrm{eV}$ region 
195 (Fig. 1a). $I_{C} / I c_{a}$ ratios measured on different calcium-bearing reference samples with known 196 elemental compositions showed good correlation with C/Ca molar ratios (Fig. S2) ( $\left.\mathrm{R}^{2} \sim 0.95\right)$ (Fig.

197 1b). The reference compounds included carbonate minerals (amorphous calcium carbonate, 198 aragonite, benstonite, calcite, dolomite), calcium-phosphate minerals (francolite, hydroxyapatite), 199 and Escherichia coli cells, and have already been described elsewhere (Benzerara et al., 2004; 200 Cosmidis \& Benzerara, 2014; Cam et al., 2015; Cosmidis et al., 2015a, 2015b). $I_{C} / I c_{a}$ ratios were used to distinguish calcium carbonate mineral phases (empirically 202 defined as $\left.I_{C} / I c_{a}<3.3\right)$ from organic materials with adsorbed $\mathrm{Ca}^{2+}$. The presence of X-ray 203 absorption features at $290.3 \mathrm{eV}$ and around $301.5 \mathrm{eV}$ was furthermore used to discriminate 204 calcium-carbonate minerals from organic matter (absorbing in the 285.0-288.7 eV range) (Brandes 205 et al., 2010) (Fig. 1a). A more quantitative assessment of carbonates versus organic carbon 206 concentrations was not attempted due to the fact that the intensity of the X-ray absorption signal $207290.3 \mathrm{eV}\left(1 \mathrm{~s} \rightarrow \pi^{*}\right.$ electronic transitions in carbonate groups) in carbonate minerals depends on 208 the orientation of the crystals with respect to the X-ray beam (Metzler et al., 2008).

\subsubsection{Determination of calcium carbonate crystallinity: splitting ratios at the Ca $L_{2,3}$-edge}

Calcium carbonate mineral phases were identified by comparison with reference spectra at

211 the $\mathrm{Ca} \mathrm{L}_{2,3}$-edge. The crystallinity of calcium carbonates was furthermore quantified using 212 calculated splitting ratios ( $\left.\mathrm{SRL}_{2}, \mathrm{SRL}_{3}\right)$, which provide a measure of the crystal field splitting at 213 the $\mathrm{Ca}_{2}$ and $\mathrm{L}_{3}$ edges, as defined in Politi et al. (2008). Typically, the $\mathrm{Ca}_{2,3}$-edge spectra of 214 amorphous calcium carbonates (ACC) have poorly split $\mathrm{L}_{2}$ and $\mathrm{L}_{3}$ peaks, while the spectra of 215 crystalline phases such as calcite display higher $\mathrm{SRL}_{2}$ and $\mathrm{SRL}_{3}$ splitting ratios characteristic of 216 well resolved split peaks (Politi et al., 2008) (Fig. 1c). 
3. RESULTS

\subsection{Types and abundances of whiting particles}

SEM was used to image and quantify the abundance of solid particles collected on filters

220 at different depths in the FGL water column throughout the 2018 whiting season. Sampled particles

221 primarily consist of centric and pennate diatoms, carbonate minerals grains, microbial cells, and

222 extracellular organic materials (Figs. 2, S1). Calcium carbonate minerals are not visible in SEM

223 images in April but are present in June, with highest abundances in the $3 \mathrm{~m}$ sample, showing the

224 shallow location of the whiting in the water column (Fig. 3). Both centric and pennate diatoms

225 increase in numbers as the summer progresses, peaking in June, while the abundance of carbonate

226 minerals peaks in August. Unfortunately, abundances of microbial cells (e.g. cyanobacteria)

227 cannot be quantified using SEM images, due to their small sizes and low density to the electron

228 beam. Both calcium carbonate minerals and diatoms sink deeper in the water column with time,

229 evidenced by counts showing decreasing abundance in the shallow water column and increasing

230 abundance at greater depth through the summer. The aspect of carbonate minerals changes through

231 time, as depicted in Figure 2a-c: early carbonate grains (June) appear smooth, while later carbonate

232 grains (August) develop pitted, rough outer surfaces as well as rounder shapes. Howver, the

233 average size of suspended carbonate grains remains relatively constant with time $(\sim 5-7 \mu \mathrm{m}$ in

234 length) through the whiting. Carbonate grains and diatoms are found within a mesh of long organic

235 filaments, $\sim 100 \mathrm{~nm}$ thick, likely corresponding to $\beta$-chitin fibrils produced by some centric diatoms

236 (Herth \& Barthlott, 1979; Gügi et al., 2015; Novis et al., 2017). These fibrils are also observed

237 aggregated with carbonates and diatoms in sediment trap samples collected at $13 \mathrm{~m}$ depth in July

2382017 (Fig. 2f, S2). Some centric diatoms from the water column samples appear to be extruding

239 EPS materials through pores of their silica valves (Fig. 1d). The brightness of this exuded material 
240 in SEM images suggests that it might be associated with heavy elements such as absorbed metallic 241 cations. and $\mathrm{Ca} \mathrm{L}_{2,3}$-edges. Abundant centric diatoms were observed, confirming SEM results, along with

247 spherical and rod-shaped microbial cells (Fig. 4). The spherical cells are relatively small $(\sim 0.8$

$248 \mu \mathrm{m}$ in diameter), and likely correspond to cyanobacteria of the genus Synechococcus, the

249 dominant autotrophs in Green Lake (Thompson et al., 1990; Schultze-Lam et al., 1997;

250 Kamennaya et al., 2020). Diatoms and bacteria are found amidst extracellular organic material, 251 forming either fibrils or thin films, and interpreted as EPS produced by microbial cells and/or 252 diatoms. Note that this EPS material, although visible on STXM transmission images, do not 253 always appear on organic carbon maps, likely due to their extreme thinness (possibly $10 \mathrm{~nm}$ or 254 thinner; Svetličić et al., 2013) which might prevent the obtention of a proper focus of the X-ray 255 beam and good absorption signal.

256 C K-edge XANES spectra obtained on Synechococcus cells exhibit a main peak at 288.2 $257 \mathrm{eV}$ (amide groups in peptides), with smaller peaks at 285.0-285.5 eV (aromatics and unsaturated 258 carbon), and shoulders at $286.6 \mathrm{eV}$ (ketonic and phenolic groups), $287.4 \mathrm{eV}$ (aliphatics, phenols 259 and/or ketones), $288.5 \mathrm{eV}$ (carboxylic groups), $289.4 \mathrm{eV}$ (hydroxyl groups, ethers, and/or C=O 260 groups in nucleic acids), and $290.3 \mathrm{eV}$ (carbonate groups) matching previously published 261 bacterial spectra (e.g, Benzerara et al., 2004; Chan et al., 2011; Cosmidis et al., 2015a) (Fig. 5). 
262 In contrast, the $\mathrm{C}$ K-edge spectra of the EPS show a main peak at $288.5 \mathrm{eV}$ (carboxylic groups),

263 consistent with a composition dominated by acidic polysaccharides (Lawrence et al., 2003; Chan

264 et al., 2009; Mitsunobu et al., 2014), with smaller peaks and shoulders around 285.0-285.5 eV

265 (aromatics and unsaturated carbon), $287.4 \mathrm{eV}$ (aliphatics, phenols and/or ketones), $288.2 \mathrm{eV}$

266 (amide groups), and $289.4 \mathrm{eV}$ (hydroxyl groups, ethers, and/or $\mathrm{C}=\mathrm{O}$ groups in nucleic acids).

267 Note that peaks at 288.5 and $289.4 \mathrm{eV}$ are also consistent with the presence of $\beta$-chitin (Lehmann

268 et al., 2009), which composes the EPS fibrils extruded by many centric diatoms (Herth \&

269 Barthlott, 1979; Novis et al., 2017).

At the $\mathrm{Ca}_{2,3}$-edge, STXM shows the presence of abundant calcium on EPS films and

271 diatoms, in particular on perforations of the frustules, from which EPS are typically exuded

272 (Herth \& Barthlott, 1979) (Fig. 6). Relatively minor amounts of calcium are detected on

273 microbial cells (see calcium maps on Fig. 4), where this element is only present as adsorbed

$274 \mathrm{Ca}^{2+}$, identifiable by a weak absorption signal at the $\mathrm{Ca} \mathrm{L}_{2,3}$-edge (IC/Ca ratios 10-50) and absence

275 of strong peaks at $290.3 \mathrm{eV}$ and $301.5 \mathrm{eV}$ (corresponding to carbonates) at the $\mathrm{C}$ K-edge. The

276 surfaces of the Synechococcus cells are enriched in adsorbed calcium compared with their

277 interiors, which can be determined by comparing the intensity of the absorption signal at the $\mathrm{C}$

278 K-edge and $\mathrm{Ca} \mathrm{L}_{2,3}$-edge on the XANES spectra extracted from a cell interior (labelled S1) and

279 cell surface (labelled L) on Figure 7. For instance, for the Synechococcus cell in Fig. 7a, $I_{C I} I_{C a}=$

28046 on the cell interior and $I_{C / I} I_{C a}=17$ on the cell surface. The calcium enrichment of the cell

281 surface may be indicative of $\mathrm{Ca}^{2+}$ adsorption on Synechococcus S-layers, as described in

282 previous studies (Thompson \& Ferris, 1990; Schultze-Lam et al., 1992). 
284 (white arrows on Fig. 4), displaying low $I_{C / I_{C a}}$ ratios ranging from 0.5 to 2.5, as well as intense

285 X-ray absorptions at $290.3 \mathrm{eV}$ and $\sim 301.5 \mathrm{eV}$, and thus interpreted as calcium carbonate

286 minerals. At the $\mathrm{Ca}_{2,3}$-edge, their calculated splitting ratios are $\mathrm{SRL}_{3} \sim 1.2-1.4$ and $\mathrm{SRL}_{2} \sim 1.3$ -

287 1.4, matching a reference amorphous calcium carbonate (ACC) (Fig. 8). ACC in the pre-whiting 288 samples is also found as small $(<500 \mathrm{~nm})$ mineral grains located on or nearby Synechococcus 289 cells (phases mapped in blue in Fig. 7). These ACC phases were not identified on SEM images, 290 possibly due to their small sizes.

291 Calcium is also concentrated in round-shaped areas within the EPS films, measuring $~ 1$

$292 \mu \mathrm{m}$ in diameter (open arrows in Fig. 4d,f; Fig. S3a). Due to their weak signal at the $\mathrm{Ca}_{\mathrm{L} 2,3}$-edge 293 as compared with ACC grains described above, they likely correspond to adsorbed $\mathrm{Ca}^{2+}$ on

294 organic material rather than to calcium-carbonate minerals. No XANES spectra were acquired on 295 these objects, preventing calculations of $I_{C /} I_{C a}$ ratios. These round shaped calcium enrichments 296 may correspond to "bag-like" EPS envelopes issued from Synechococcus cells, which can 297 dissociate from the cells and have high $\mathrm{Ca}^{2+}$ adsorption capacity (Kamennaya et al., 2020).

\subsubsection{Whiting sample (sediment trap)}

STXM analyses were performed on whiting particles collected in a sediment trap placed 300 in the FGL water column at $13.5 \mathrm{~m}$ depth between July 12 and July 21, 2017. The sample

301 contains abundant calcium carbonate particles, measuring up to $7 \mu \mathrm{m}$ in length, and identified as

302 calcite based on the similarity of their $\mathrm{Ca}_{2,3}$-edge XANES spectra with that of a reference 303 calcite (Fig. 9, S4), in agreement with previous studies of whitings at FGL (Thompson et al.,

304 1990; Schultze-Lam et al., 1997). Calculated $I_{C /} I_{C a}$ ratios for these calcite grains range between 3052.5 and 3.3, and splitting ratios at the $\mathrm{Ca}_{2,3}$-edge are $\mathrm{SRL}_{2} \sim 1.6-1.7$ and $\mathrm{SRL}_{3} \sim 1.8-2.0$ (Fig. 
8), consistent with crystalline calcite (Politi et al., 2008). C K-edge XANES spectra obtained on

307 the calcite grains sometimes display absorption peaks at 288.2-288.5 eV (amides and

308 carboxylics), suggesting that organic compounds may be adsorbed onto or incorporated within

309 the mineral particles (Fig. 9d).

310 The calcite grains are forming aggregates also containing centric diatoms and organic

311 material, present either as fibrils, or as organic particles surrounding the minerals.

312 Synechococcus cells were not observed in the sediment trap sample. The C K-edge XANES

313 spectra of the organic fibrils and particles display main peaks at $288.5 \mathrm{eV}$ (carboxylic groups)

314 and $288.2 \mathrm{eV}$ (amide groups), with smaller peaks or shoulders at 285.0 and $285.5 \mathrm{eV}$ (aromatics

315 and unsaturated carbon), $286.6 \mathrm{eV}$ (ketonic and phenolic groups), $287.4 \mathrm{eV}$ (aliphatics, phenols

316 and/or ketones), $289.4 \mathrm{eV}$ (hydroxyl groups, ethers, and/or $\mathrm{C}=\mathrm{O}$ groups in nucleic acids). This

317 composition is similar to that of EPS and diatom $\beta$-chitin fibrils previously described in pre-

318 whiting samples from the water column, with an increased contribution from amide groups

319 which may be derived from proteins issued from decomposing microbial cells. The organic

320 fibrils and particles display high $I_{C} / I_{c a}$ ratios (73-605) and no absorption signal from carbonates

321 at the $\mathrm{C} \mathrm{K}$-edge, showing that calcium is only present as minor amounts of adsorbed $\mathrm{Ca}^{2+}$.

322 Similarly, the diatoms display C K-edge XANES spectra consistent with cellular material with

323 main absorption features characteristic of amides and carboxylic groups and absence of strong

324 carbonate signal, with relatively high $I_{C} / I_{c a}$ ratios (e.g. $I_{C} I_{c a}=61$ for the diatom fragment in Fig.

325 S4) consistent with the presence of adsorbed $\mathrm{Ca}^{2+}$ only.

$326 \quad$ 3.2.3 Sediment core samples

327 STXM analyses of sediment core samples from the bottom of FGL are presented in

328 Figure 10 as well as Supplementary figures S5 and S6. The sediment contains abundant calcium 
329 carbonate grains, identified as calcite based on their $\mathrm{Ca}_{2,3}$-edge spectroscopic signature, and 330 similar in shape and size with those observed in the whiting samples. This observation is

331 consistent with isotopic studies suggesting that carbonate precipitation in the oxic zone of the 332 lake is the primary source of carbonate in the sediments (Havig et al., 2017). $I_{C} / I_{C a}$ ratios 333 measured on the sediment calcite particles range between 2.1 and 2.6, and splitting ratios at $\mathrm{Ca}$ $334 \mathrm{~L}_{2,3}$-edges are $\mathrm{SRL}_{3} \sim 1.9-3.2$ and $\mathrm{SRL}_{2} \sim 1.8$ and $2.2\left(\mathrm{SRL}_{2}\right)$ (Fig. 8), indicating increased 335 crystallinity compared with the whiting calcite particles from the sediment trap. C K-edge 336 XANES spectra obtained on these sedimentary calcite particles display peaks at 288.2-288.5 eV, 337 again showing possible adsorption of incorporation of organic molecules.

338 Abundant diatoms, sometimes fragmented, are also observed in the sediment. Diatoms 339 are mostly centric, with fewer pennate forms (e.g., Fig 10c, S5). The diatoms are associated with 340 higher amounts of calcium compared with diatoms from the sediment trap, as visible on STXM 341 calcium maps. This abundance of calcium is reflected in low $I_{C} / I_{C a}$ ratios ranging from 3.4 to 7.5. 342 Combined with strong absorption signals at $290.3 \mathrm{eV}$ at the $\mathrm{C}$ K-edge (see in particular Fig.

$343 \mathrm{~S} 6 \mathrm{~b})$, low $I_{C} / I_{C a}$ ratios indicate the presence of fine calcium carbonate phases associated with the 344 diatoms frustules. Calculated splitting ratios at the $\mathrm{Ca}_{2,3}$-edge range between those of ACC and 345 calcite $\left(\mathrm{SRL}_{2} \sim 1.3-1.6\right.$ and $\left.\mathrm{SRL}_{3} \sim 1.1-1.5\right)$, corresponding to either ACC or poorly crystalline 346 calcite.

347 Organic matter in the sediment samples is found in diatoms and rare extracellular fibrils 348 (Fig. S5), as well as dense organic-rich particles found around diatoms and calcite grains, 349 measuring up to $\sim 5 \mu \mathrm{m}$ (see one of these large organic particles in Fig. S6). These organic 350 particles have a C K-edge signature similar to that of organic particles in the sediment traps. 


\section{DISCUSSION}

\subsection{Biological mechanisms in the FGL whiting}

The whiting at FGL corresponds to the conspicuous precipitation of calcite crystals in the

354 shallow water column of the lake, first observed at $\sim 3 \mathrm{~m}$ depth in June (although find ACC grains

355 are present associated with organics are present as early as April). Calcite saturation indices of $\sim 1$

356 at the surface of FGL (Takahashi et al., 1968; Havig et al., 2015) can be compared to indices of

$357 \sim 0.3$ in waters of the Bahama Banks (Broecker \& Takahashi, 1966), where marine whitings are

358 regularly observed. Previous work has suggested that variability in saturation state leads to

359 measurable changes in whiting precipitation rates (Morse et al., 2003), suggesting that

360 precipitation rates at FGL have the potential to be fast in comparison to marine whitings. It is

361 unclear whether or not photosynthetic organisms such as cyanobacteria and diatoms play a role in

362 calcite precipitation through $\mathrm{CO}_{2}$ uptake and localized alkalinization. Indeed, calcite abundances

363 (peaking at $\sim 4 \mathrm{~m}$ depth in August) are uncorrelated with maximum abundances of diatoms (at $\sim 8$

$364 \mathrm{~m}$ in June) (Fig. 3), and previous studies found no correlation in space and time between peak

365 abundances of calcite and Synechoccus (Schultze-Lam et al., 1997).

366 However, it is obvious that organic-mineral interactions involving microbial cells and EPS

367 play a crucial role in calcium carbonate mineralization at the onset of the whiting. In April, STXM 368 analyses reveal fine ACC phases covering abundant EPS derived from diatoms (Fig. 6), as well as 369 cyanobacterial cells (Synechococcus) (Fig. 7). The precipitation of ACC minerals is likely 370 facilitated by the adsorption of $\mathrm{Ca}^{2+}$ on organic surfaces such as Synechococus cells (Fig. 7), 371 diatom EPS exuded from apertures of the silica valves (Figs. 2d, 6), and possibly "bag-like" empty

372 EPS envelopes detached from Synechococcus cells (Fig. 4d,f) (Kamennaya et al., 2020). A 373 significant portion of the diatom EPS likely consists of $\beta$-chitin fibrils, found associated with 
374 calcite particles later in the summer (Figs. 2, S2). This interpretation is supported by the fact that 375 microorganisms degrading chitin have been described in the FGL monimolimion (Rojas et al., 376 2021).

At the molecular level, adsorption of $\mathrm{Ca}^{2+}$ ions can occur on negatively charged

378 functional groups such as deprotonated carboxylic groups in acidic polysaccharides and proteins.

379 In FGL waters, at pH 6-8, carboxyl groups exist in a deprotonated state (Beveridge, 1981), and

380 photosynthetic $\mathrm{CO}_{2}$ uptake may result in local $\mathrm{pH}$ increases surrounding cyanobacteria and

381 diatoms, further facilitating deprotonation and calcium binding. Likewise, $\beta$-chitin molecules

382 forming an important part of diatom EPS present $\mathrm{C}=\mathrm{O}, \mathrm{O}-\mathrm{H}$, and $\mathrm{N}-\mathrm{H}$ groups as well as oxygen

383 atoms with affinity for calcium ions, and chitin has been previously described as a nucleating

384 agent for both amorphous and crystalline calcium carbonate biominerals (Ehrlich, 2010).

While a role of Synechococcus S-layers in calcium carbonate nucleation and templating

386 has been proposed in earlier studies (Thompson \& Ferris, 1990; Schultze-Lam et al., 1992),

387 implication of diatom EPS in whiting at FGL is proposed here for the first time. Recent studies

388 have described spatial associations of centric diatoms with calcium-carbonates precipitates in the 389 water column of Lake Stechlin (Geramany) (Fuchs et al., 2016) as well as in a southwest Florida 390 whiting event (Long et al., 2017). In the second example, amorphous and crystalline $\mathrm{CaCO}_{3}$ 391 particles were observed along the diatom girdle bands, which was explained by the unique surface 392 chemistry and chemical microenvironment in this region of the diatom frustule associated with 393 cell division.

394 It is not clear why the role of diatoms and exuded EPS has been overlooked in previous 395 studies of the whitings at FGL. The high abundance of diatoms in the lake sediments (Figs. 10, S5, 396 S6) indicate that they have been thriving in past decades, and their presence is mentioned in several 
397 older articles (Culver \& Brunskill, 1969; Thompson et al., 1990; Schultze-Lam et al., 1997). Nano-

398 particulate ACC nucleating on diatom EPS in the early spring may have been unnoticed in the past

399 due to unsuitable observation techniques. It is also possible that whiting nucleation mechanisms at

400 FGL have evolved over time, with varying contributions of cyanobacteria versus diatoms through

401 the lake's recent history. Predominant mechanisms of calcium carbonate nucleation may shift

402 depending on the microbial community dynamics in the water column, as a result of changes in

403 climatic conditions and/or in the nutrient status of the lake.

404 In the summer, during the peak of the whiting, calcium carbonate is found as larger (up to $405 \sim 7 \mu \mathrm{m})$ crystalline calcite grains, aggregating with diatoms as well as EPS materials including 406 abundant $\beta$-chitin fibrils (Figs. 2, 9). It is unclear whether the whiting calcite particles correspond 407 to the crystallization and growth of ACC particles observed in pre-whiting samples, although ACC 408 is a common precursor phase to crystalline calcite in biological precipitation systems (Weiner et $409 a l ., 2005)$. In particular, ACC is a precuror phase for $\mathrm{CaCO}_{3}$ mineralization on microbial EPS 410 (Enyedi et al., 2020; Shiraishi et al., 2020). Intermediate phases between nano-ACC particles and 411 calcite crystals measuring several micrometers in lengths were not observed, which may be due to 412 fast calcite growth in supersaturated solutions (see next section of the discussion).

413 In the sediment trap sample (July), organic materials and diatoms associated with the 414 calcite particles display very small amounts of adsorbed $\mathrm{Ca}^{2+}$ as compared with pre-whiting 415 samples (see high $\mathrm{I}_{\mathrm{C}} / \mathrm{I}_{\mathrm{Ca}}$ values in Figure 8). Low amounts of calcium adsorbed on organics and 416 diatoms in this whiting sample may thus suggest that calcite minerals grown at the expense of $\mathrm{Ca}^{2+}$ 417 initially adsorbed on biological materials. 
The end of the whiting season is marked by a decline in calcite mineral abundances in the

421 with respect to calcite in the late summer (Brunskill, 1969), the termination of the whiting may be

422 linked with the decline in abundances of photosynthesizing organisms in shallow waters with time,

423 leading to a shortage of organic surfaces for calcium carbonate heterogeneous nucleation.

The duration of the whiting is additionally controlled by the settling rate of mineral

425 particles. Settling rates of mineral grains exponentially increase with size, as shown by Gibbs et

426 al. (1971). This phenomenon results in a dramatic increase in settling rate as minerals grow longer

427 than $10 \mu \mathrm{m}$ in length. Based on our assessment of calcite grain sizes, average whiting calcite grains

428 (5-7 $\mu \mathrm{m}$ in length) have a settling rate of $\sim 1 \mathrm{~m} /$ day in still waters (based on calculations from Gibbs

429 et al., 1971). Particles likely have somewhat longer residence times in the turbulent mixolimnion

430 than these still-water settling rates imply, and smaller particles likely remain suspended in the

431 upper portion of the lake for longer, contributing to the light scattering by carbonate grains, giving

432 the lake its turquoise color. However, minerals in the mixolimnion likely grow quite fast (up to 2

$433 \mu \mathrm{m} /$ day, based on saturation state rate studies conducted by Wolthers et al., 2012), sinking faster

434 as they grow, and ultimately fall out of the water column, settling in the sediments. Thus, a mineral

435 can quickly grow to 5-7 $\mu \mathrm{m}$ in length over the span of 2-3 days, sinking as it grows. A mineral 1

$436 \mu \mathrm{m}$ in size at the surface will sink $<0.5 \mathrm{~m}$ in a day but grow to a size of $3 \mu \mathrm{m}$ over the same span

437 of time. Small minerals, on the order of $<5 \mu \mathrm{m}$ in size, are not found suspended in the water

438 column, likely because the growth rate of these grains is fast following nucleation on organic

439 templates. Minerals larger than $15 \mu \mathrm{m}$ were not found suspended in the water column, consistent

440 with their calculated very short residence time. All told, the residence time of a mineral grain in 
441 the upper $10 \mathrm{~m}$ of the lake is estimated to be less than 7 days when taking into account combined 442 growth and sinking. As demonstrated above, calcite particles are furthermore frequently found in 443 aggregates formed by diatom frustules and EPS, which would also increase settling rates. In order 444 to support the continued growth and settling of mineral grains, nucleation of new minerals must 445 be continuous throughout the duration of the whiting event.

446 Abundance of calcite grains in the FGL sediments (Figs. 10, S5, S6) suggests that settling 447 whiting particles reach the bottom of the lake despite some dissolution in the mixolimnion in the 448 late summer (as evidenced by corroded grain surfaces below $\sim 8 \mathrm{~m}$ depth in August and September; 449 Figs. 2, 3, S1). Calcite dissolution below $\sim 8 \mathrm{~m}$ is explained by the development of slightly 450 understaturated conditions (Havig et al., 2015), possibly due to cumulative respiratory $\mathrm{CO}_{2}$ build451 up through the summer. The sedimented calcite particles display similar shapes and sizes to those 452 found in the water column, but they are slightly more crystalline (Fig. 8b). Calcite in the sediments 453 is found in association with diatom frustules and organic materials, which can be coated by 454 important amounts of calcium (Fig. 8a), reflecting the higher concentrations of dissolved $\mathrm{Ca}^{2+}$ in 455 the lake monimolimnion (Havig et al., 2015). Calcite grains and diatoms are the main components 456 of FGL bottom sediments, confirming previous studies, and suggesting that these sediments record 457 biogeochemical signals (such as carbon isotopic signatures) from the lake surface waters (Havig 458 et al., 2017). 
This microscopy study of the annual whiting at Fayetteville Green Lake highlights the role

461 of photosynthetic microorganisms (cyanobacteria and diatoms) and their exuded polymers (EPS)

462 in calcite mineralization through nucleation of an ACC precursor phase. This work describes a

463 previously overlooked role of diatoms and their EPS in calcite precipitation, a mechanism that may

464 be relevant to different types of environments experiencing whiting events.

\section{ACKNOWLEDGMENTS}

This work was funded through the Penn State Energy and Environmental Sustainability

467 Laboratories (EESL) Green Program and Pennsylvania Space Grant Consortium awards to Chloe

468 Stanton. The authors are indebted to the staff at Green Lakes State Park (NY) for their assistance.

469 Karim Benzerara (Sorbonne Université, CNRS) is thanked for sharing XANES reference spectra,

470 and Stephen Romaniello (University of Tennessee, Knoxville) is thanked for providing a FGL

471 sediment trap sample.

472 Part of the research described in this paper was performed at the Canadian Light Source,

473 a national research facility of the University of Saskatchewan, which is supported by the Canada

474 Foundation for Innovation (CFI), the Natural Sciences and Engineering Research Council

475 (NSERC), the National Research Council (NRC), the Canadian Institutes of Health Research

476 (CIHR), the Government of Saskatchewan, and the University of Saskatchewan. This research

477 used resources of the Advanced Light Source, a U.S. DOE Office of Science User Facility under 478 contract no. DE-AC02-05CH11231. 
480 Bathurst RGC (1966) Boring algae, micrite envelopes and lithification of molluscan biosparites. Geological Journal 5, 15-32.

Benzerara K, Bolzoni R, Monteil C, Beyssac O, Forni O, Alonso B, Asta MP, Lefevre C (2021) The gammaproteobacterium Achromatium forms intracellular amorphous calcium carbonate and not (crystalline) calcite. Geobiology 19, 199-213.

Benzerara K, Skouri-Panet F, Li J, Ferard C, Gugger M, Laurent T, Couradeau E, Ragon M, Cosmidis J, Menguy N, Margaret-Oliver I, Tavera R, Lopez-Garcia P, Moreira D (2014) Intracellular Ca-carbonate biomineralization is widespread in cyanobacteria. Proceedings of the National Academy of Sciences 111, 10933-10938.

Benzerara K, Yoon TH, Tyliszczak T, Constantz B, Spormann AM, Brown GE (2004) Scanning transmission X-ray microscopy study of microbial calcification. Geobiology 2, 249-259. Beveridge TJ (1981) Ultrastructure, Chemistry, and Function of the Bacterial Wall. In: International Review of Cytology (eds. Bourne GH, Danielli JF, Jeon KW). Academic Press, pp. 229-317.

Boss SK, Neumann A (1993) Physical versus chemical processes of "whiting" formation in the Bahamas. Carbonates and Evaporites.

Brandes JA, Wirick S, Jacobsen C (2010) Carbon $K$-edge spectra of carbonate minerals. Journal of Synchrotron Radiation 17, 676-682.

Broecker W (2012) Section 9. Whitings. Geochemical Perspectives 1, 249-250.

Broecker WS, Sanyal A, Takahashi T (2000) The origin of Bahamian Whitings revisited. Geophysical Research Letters 27, 3759-3760.

Broecker WS, Takahashi T (1966) Calcium carbonate precipitation on the Bahama Banks. Journal of Geophysical Research (1896-1977) 71, 1575-1602.

Brunskill GJ (1969) Fayetteville Green Lake, New York. II. Precipitation and Sedimentation of Calcite in a Meromictic Lake with Laminated Sediments. Limnology and Oceanography 14, 830-847.

Cam N, Georgelin T, Jaber M, Lambert J-F, Benzerara K (2015) In vitro synthesis of amorphous $\mathrm{Mg}-$, Ca-, Sr- and Ba-carbonates: What do we learn about intracellular calcification by cyanobacteria? Geochimica et Cosmochimica Acta 161, 36-49.

Chan CS, Fakra SC, Edwards DC, Emerson D, Banfield JF (2009) Iron oxyhydroxide mineralization on microbial extracellular polysaccharides. Geochimica et Cosmochimica Acta 73, 3807-3818.

Chan CS, Fakra SC, Emerson D, Fleming EJ, Edwards KJ (2011) Lithotrophic iron-oxidizing bacteria produce organic stalks to control mineral growth: implications for biosignature formation. The ISME Journal 5, 717-727.

Chen X, Romaniello SJ, Anbar AD (2021) Preliminary exploration of molybdenum isotope fractionation during coprecipitation of molybdate with abiotic and microbial calcite. Chemical Geology 566, 120102.

Cosmidis J, Benzerara K (2014) Soft X-ray Scanning Transmission Spectromicroscopy. In: Biomineralization Sourcebook: Characterization of Biominerals and Biomimetic Materials. E. DiMasi and L.B. Gower, London, UK, pp. 115-133.

Cosmidis J, Benzerara K, Guyot F, Skouri-Panet F, Duprat E, Férard C, Guigner J-M, Babonneau F, Coelho C (2015a) Calcium-Phosphate Biomineralization Induced by Alkaline 
Phosphatase Activity in Escherichia coli: Localization, Kinetics, and Potential Signatures in the Fossil Record. Frontiers in Earth Science 3. Cosmidis J, Benzerara K, Nassif N, Tyliszczak T, Bourdelle F (2015b) Characterization of Caphosphate biological materials by scanning transmission X-ray microscopy (STXM) at the Ca L2,3-, P L2,3- and C K-edges. Acta Biomaterialia 12, 260-269.

528 Culver DA, Brunskill GJ (1969) Fayetteville Green Lake, New York. V. Studies of primary production and zooplankton in a meromictic marl lake: primary production in Green Lake. Limnology and Oceanography 14, 862-873. DeMott LM, Napieralski SA, Junium CK, Teece M, Scholz CA (2020) Microbially influenced lacustrine carbonates: A comparison of Late Quaternary Lahontan tufa and modern thrombolite from Fayetteville Green Lake, NY. Geobiology 18, 93-112. carbonate sediment whitings and potential relationship to wind-driven Langmuir circulation. Biogeosciences 6, 487-500.

Dittrich M, Kurz P, Wehrli B (2004) The Role of Autotrophic Picocyanobacteria in Calcite Precipitation in an Oligotrophic Lake. Geomicrobiology Journal 21, 45-53.

Dittrich M, Obst M (2004) Are Picoplankton Responsible for Calcite Precipitation in Lakes? AMBIO: A Journal of the Human Environment 33, 559-564.

Dupraz C, Reid RP, Braissant O, Decho AW, Norman RS, Visscher PT (2009) Processes of carbonate precipitation in modern microbial mats. Earth-Science Reviews 96, 141-162.

Dupraz C, Visscher PT (2005) Microbial lithification in marine stromatolites and hypersaline mats. Trends in Microbiology 13, 429-438.

Ehrlich H (2010) Chitin and collagen as universal and alternative templates in biomineralization. International Geology Review 52, 661-699.

Ehrlich H, Motylenko M, Sundareshwar PV, Ereskovsky A, Zgłobicka I, Noga T, Płociński T, Tsurkan MV, Wyroba E, Suski S, Bilski H, Wysokowski M, Stöcker H, Makarova A, Vyalikh D, Walter J, Molodtsov SL, Bazhenov VV, Petrenko I, Langer E, Richter A, Niederschlag E, Pisarek M, Springer A, Gelinsky M, Rafaja D, Witkowski A, Meyer DC, Jesionowski T, Kurzydłowski KJ (2016) Multiphase Biomineralization: Enigmatic Invasive Siliceous Diatoms Produce Crystalline Calcite. Advanced Functional Materials 26, 2503-2510.

Enyedi NT, Makk J, Kótai L, Berényi B, Klébert S, Sebestyén Z, Molnár Z, Borsodi AK, LeélÖssy S, Demény A, Németh P (2020) Cave bacteria-induced amorphous calcium carbonate formation. Scientific Reports 10, 8696.

Fuchs A, Selmeczy GB, Kasprzak P, Padisák J, Casper P (2016) Coincidence of sedimentation peaks with diatom blooms, wind, and calcite precipitation measured in high resolution by a multi-trap. Hydrobiologia 763, 329-344.

Fulton JM, Arthur MA, Thomas B, Freeman KH (2018) Pigment carbon and nitrogen isotopic signatures in euxinic basins. Geobiology 16, 429-445.

Gibbs RJ, Matthews MD, Link DA (1971) The relationship between sphere size and settling velocity. Journal of Sedimentary Research 41, 7-18.

Gomez FJ, Mlewski C, Boidi FJ, Farías ME, Gérard E (2018) Calcium Carbonate Precipitation in Diatom-rich Microbial Mats: The Laguna Negra Hypersaline Lake, Catamarca, Argentina. Journal of Sedimentary Research 88, 727-742. 
Gügi B, Le Costaouec T, Burel C, Lerouge P, Helbert W, Bardor M (2015) Diatom-Specific Oligosaccharide and Polysaccharide Structures Help to Unravel Biosynthetic Capabilities in Diatoms. Marine Drugs 13, 5993-6018. Havig JR, Hamilton TL, McCormick M, McClure B, Sowers T, Wegter B, Kump LR (2017) stratified Fayetteville Green Lake, New York, U.S.A.: Carbon isotopes at FGL. Limnology and Oceanography.

Havig JR, McCormick ML, Hamilton TL, Kump LR (2015) The behavior of biologically important trace elements across the oxic/euxinic transition of meromictic Fayetteville Green Lake, New York, USA. Geochimica et Cosmochimica Acta 165, 389-406.

Herth W, Barthlott W (1979) The site of $\beta$-chitin fibril formation in centric diatoms. I. Pores and fibril formation. Journal of Ultrastructure Research 68, 6-15. Hitchcock A (2012) aXis 2000 - Analysis of X-ray Images and Spectra. Hodell DA, Schelske CL, Fahnenstiel GL, Robbins LL (1998) Biologically induced calcite and its isotopic composition in Lake Ontario. Limnology and Oceanography 43, 187-199.

\section{Hunter SE (2012) Spatio-temporal Variability in the Phototrophic Chemocline Community at} Fayetteville Green Lake (new York) (Master Thesis).

Kamennaya NA, Hu P, Jansson C (2020) Sedimentation of ballasted cells-free EPS in meromictic Fayetteville Green Lake. Geobiology 18, 80-92.

Kirkwood AE, Shea T, Jackson LJ, McCauley E (2007) Didymosphenia geminata in two Alberta headwater rivers: an emerging invasive species that challenges conventional views on algal bloom development. Canadian Journal of Fisheries and Aquatic Sciences 64, 1703-1709. Küchler-Krischun J, Kleiner J (1990) Heterogeneously nucleated calcite precipitation in Lake Constance. A short time resolution study. Aquatic Sciences 52, 176-197.

Lawrence JR, Swerhone GDW, Leppard GG, Araki T, Zhang X, West MM, Hitchcock AP (2003) Scanning Transmission X-Ray, Laser Scanning, and Transmission Electron Microscopy Mapping of the Exopolymeric Matrix of Microbial Biofilms. Applied and Environmental Microbiology 69, 5543-5554.

Lehmann J, Solomon D, Brandes J, Fleckenstein H, Jacobson C, Thieme J (2009) SynchrotronBased Near-Edge X-Ray Spectroscopy of Natural Organic Matter in Soils and Sediments. In: Biophysico-Chemical Processes Involving Natural Nonliving Organic Matter in Environmental Systems (eds. Senesi N, Xing B, Huang PM). John Wiley \& Sons, Inc., Hoboken, NJ, USA, pp. 729-781.

Lisle JT, Robbins LL (2016) Viral Lysis of Photosynthesizing Microbes As a Mechanism for Calcium Carbonate Nucleation in Seawater. Frontiers in Microbiology 7.

Long JS, Hu C, Robbins LL, Byrne RH, Paul JH, Wolny JL (2017) Optical and biochemical properties of a southwest Florida whiting event. Estuarine, Coastal and Shelf Science 196, 258268.

Martignier A, Pacton M, Filella M, Jaquet J-M, Barja F, Pollok K, Langenhorst F, Lavigne S, Guagliardo P, Kilburn MR, Thomas C, Martini R, Ariztegui D (2017) Intracellular amorphous carbonates uncover a new biomineralization process in eukaryotes. Geobiology 15, 240-253. Metzler R, Zhou D, Abrecht M, Chiou J-W, Guo J, Ariosa D, Coppersmith S, Gilbert P (2008) Polarization-dependent imaging contrast in abalone shells. Physical Review B 77. 
609 Meyer KM, Macalady JL, Fulton JM, Kump LR, Schaperdoth I, Freeman KH (2011) Carotenoid 610 biomarkers as an imperfect reflection of the anoxygenic phototrophic community in meromictic 611 Fayetteville Green Lake. Geobiology 9, 321-329.

612 Mitsunobu S, Zhu M, Takeichi Y, Ohigashi T, Suga H, Makita H, Sakata M, Ono K, Mase K,

613 Takahashi Y (2014) Nanoscale Identification of Extracellular Organic Substances at the

614 Microbe-Mineral Interface by Scanning Transmission X-ray Microscopy. Chemistry Letters 44,

615 91-93.

616 Monteil CL, Benzerara K, Menguy N, Bidaud CC, Michot-Achdjian E, Bolzoni R, Mathon FP, 617 Coutaud M, Alonso B, Garau C, Jézéquel D, Viollier E, Ginet N, Floriani M, Swaraj S, Sachse

618 M, Busigny V, Duprat E, Guyot F, Lefevre CT (2021) Intracellular amorphous Ca-carbonate and 619 magnetite biomineralization by a magnetotactic bacterium affiliated to the Alphaproteobacteria.

620 The ISME Journal 15, 1-18.

621 Morse JW, Gledhill DK, Millero FJ (2003) CaCO3 precipitation kinetics in waters from the great

622 Bahama bank:: Implications for the relationship between bank hydrochemistry and whitings.

623 Geochimica et Cosmochimica Acta 67, 2819-2826.

624 Novis P, Schallenberg M, Saulnier-Talbot É, Kilroy C, Reid M (2017) The diatom Lindavia intermedia identified as the producer of nuisance pelagic mucilage in lakes. New Zealand Journal of Botany 55, 479-495.

Oduro H, Kamyshny A, Zerkle AL, Li Y, Farquhar J (2013) Quadruple sulfur isotope constraints on the origin and cycling of volatile organic sulfur compounds in a stratified sulfidic lake. Geochimica et Cosmochimica Acta 120, 251-262.

Politi Y, Metzler RA, Abrecht M, Gilbert B, Wilt FH, Sagi I, Addadi L, Weiner S, Gilbert PUPA (2008) Transformation mechanism of amorphous calcium carbonate into calcite in the sea urchin larval spicule. Proceedings of the National Academy of Sciences 105, 17362-17366.

Purkis S, Cavalcante G, Rohtla L, Oehlert AM, Harris P (Mitch), Swart PK (2017)

Hydrodynamic control of whitings on Great Bahama Bank. Geology 45, 939-942.

Robbins LL, Blackwelder PL (1992) Biochemical and ultrastructural evidence for the origin of whitings: A biologically induced calcium carbonate precipitation mechanism. Geology 20, 464. Robbins LL, Tao Y, Evans CA (1997) Temporal and spatial distribution of whitings on Great Bahama Bank and a new lime mud budget. Geology 25, 947-950.

Rojas CA, Torio ADS, Park S, Bosak T, Klepac-Ceraj V (2021) Organic electron donors and terminal electron acceptors structure anaerobic microbial communities and interactions in a permanently stratified sulfidic lake. bioRxiv 2021.02.16.431432.

Schultze-Lam S, Harauz G, Beveridge TJ (1992) Participation of a cyanobacterial S layer in finegrain mineral formation. Journal of Bacteriology 174, 7971-7981.

Schultze-Lam S, Schultze-Lam S, Beveridge TJ, Des Marais DJ (1997) Whiting events: Biogenic origin due to the photosynthetic activity of cyanobacterial picoplankton. Limnology and Oceanography 42, 133-141.

Shinn EA, Steinen RP, Lidz BH, Swart PK (1989) Whitings, a sedimentologic dilemma. Journal of Sedimentary Research 59, 147-161.

651 Cosmochimica Acta 285, 55-69.

652 Shnyukova EI, Zolotareva EK (2015) Diatom Exopolysaccharides: a Review. International

653 Journal on Algae 17. 
654 Stabel H-H (1986) Calcite precipitation in Lake Constance: Chemical equilibrium,

655 sedimentation, and nucleation by algae1. Limnology and Oceanography 31, 1081-1094.

656 Svetličić V, Žutić V, Pletikapić G, Radić TM (2013) Marine Polysaccharide Networks and

657 Diatoms at the Nanometric Scale. International Journal of Molecular Sciences 14, 20064-20078.

658 Swart PK, Oehlert AM, Mackenzie GJ, Eberli GP, Reijmer JJG (2014) The fertilization of the

659 Bahamas by Saharan dust: A trigger for carbonate precipitation? Geology 42, 671-674.

660 Takahashi T, Broecker W, Li YH, Thurber D (1968) Chemical and Isotopic Balances for a

661 Meromictic Lake. Limnology and Oceanography 13, 272-292.

662 Thompson JB (2000) Microbial Whitings. In: Microbial Sediments. Springer, Berlin, Heidelberg,

663 pp. 250-260.

664 Thompson JB, Ferris FG (1990) Cyanobacterial precipitation of gypsum, calcite, and magnesite

665 from natural alkaline lake water. Geology 18, 995.

666 Thompson JB, Ferris FG, Smith DA (1990) Geomicrobiology and Sedimentology of the

667 Mixolimnion and Chemocline in Fayetteville Green Lake, New York. PALAIOS 5, 52-75.

668 Urbani R, Sist P, Pletikapić G, Radić TM, Svetličić V, Žutic V (2012) Diatom Polysaccharides:

669 Extracellular Production, Isolation and Molecular Characterization. The Complex World of

670 Polysaccharides.

671 Weiner S, Sagi I, Addadi L (2005) Choosing the Crystallization Path Less Traveled. Science 309,

$672 \quad 1027-1028$.

673 Winsborough BM (2000) Diatoms and Benthic Microbial Carbonates. In: Microbial Sediments

674 (eds. Riding RE, Awramik SM). Springer, Berlin, Heidelberg, pp. 76-83.

675 Winsborough BM, Golubić S (1987) The Role of Diatoms in Stromatolite Growth: Two

676 Examples from Modern Freshwater Settings1. Journal of Phycology 23, 195-201.

677 Wolthers M, Nehrke G, Gustafsson JP, Van Cappellen P (2012) Calcite growth kinetics:

678 Modeling the effect of solution stoichiometry. Geochimica et Cosmochimica Acta 77, 121-134.

679 Zerkle AL, Kamyshny A, Kump LR, Farquhar J, Oduro H, Arthur MA (2010) Sulfur cycling in a

680 stratified euxinic lake with moderately high sulfate: Constraints from quadruple $\mathrm{S}$ isotopes.

681 Geochimica et Cosmochimica Acta 74, 4953-4970.

682 Zhu T, Dittrich M (2016) Carbonate Precipitation through Microbial Activities in Natural

683 Environment, and Their Potential in Biotechnology: A Review. Frontiers in Bioengineering and

684 Biotechnology 4.

685 

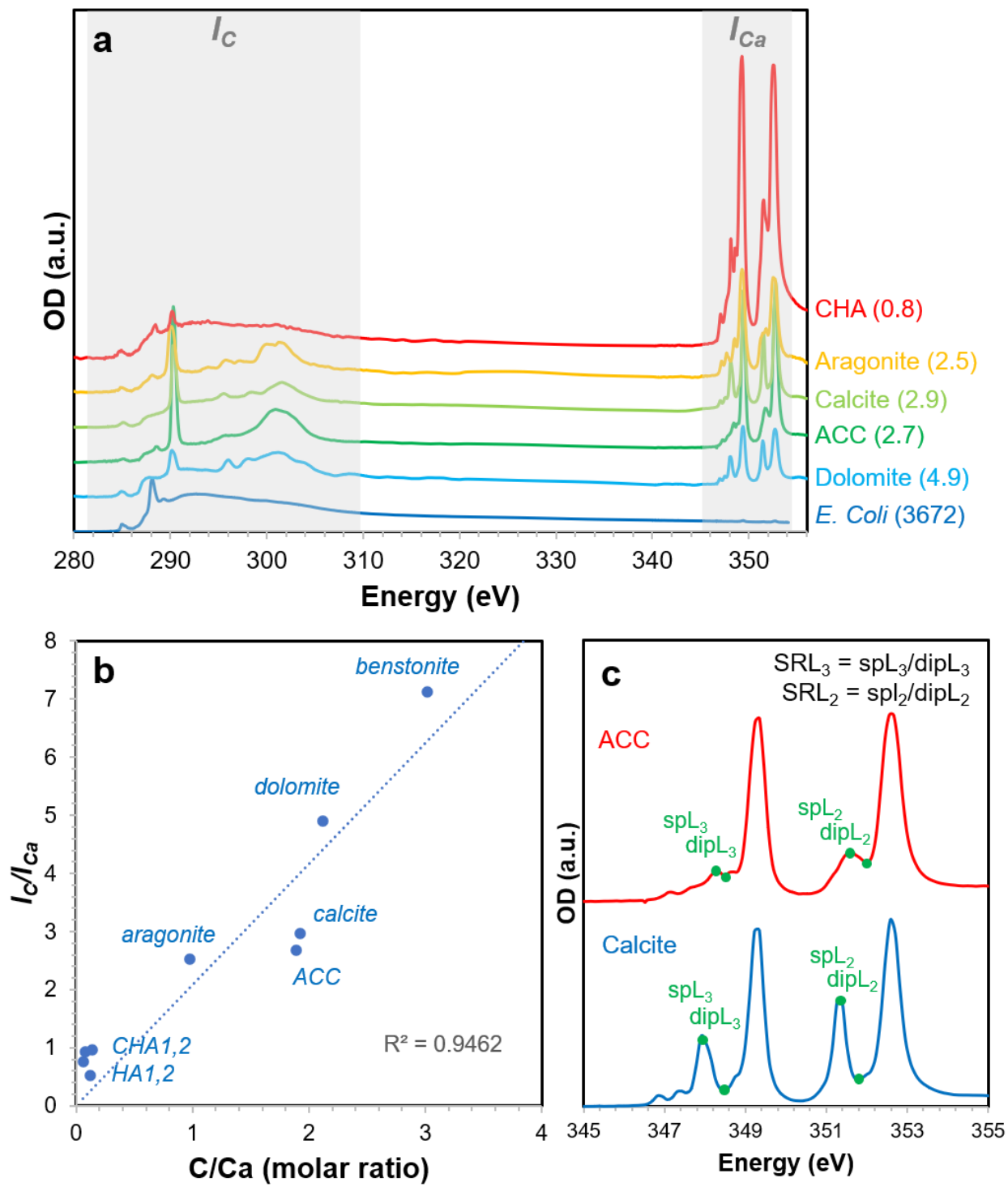

688 Figure 1. STXM methods for the calculation of $I_{C} / I_{C a}$ ratios and splitting ratios $\left(\mathrm{SRL}_{2}\right.$ and

$689 \mathrm{SRL}_{3}$ ). (a) XANES spectra of several reference compounds spanning the $\mathrm{C} \mathrm{K}$ - and $\mathrm{Ca} \mathrm{L}_{2,3}$-edges,

690 and calculated $I_{C} / I_{C a}$ ratios. $I_{C} / I_{C a}$ is calculated as the ratio of the areas under the curve in the

$691 \quad 280-310 \mathrm{eV}$ region versus the $345-354 \mathrm{eV}$ region (shaded areas). Calculated $I_{C} / I_{C a}$ ratios are

692 noted (numbers in brackets). The C K-edge spectra of carbonate minerals typically display strong

693 absorption peaks at $290.3 \mathrm{eV}$ and broad absorption bands around $301.5 \mathrm{eV}$. Some of the mineral 
694 references contain minor amounts of organics, detectable as small peaks in the 285.0-288.7 eV

695 region. ACC: amorphous calcium carbonate; CHA: carbonated hydroxyapatite (francolite). (b)

696 Plot showing the correlation between $I_{C} / I_{C a}$ ratios and measured $\mathrm{C} / \mathrm{Ca}$ molar ratios for different

697 calcium-bearing reference minerals. ACC: amorphous calcium carbonate; CHA: carbonated

698 hydroxyapatite (francolite), HA: hydroxyapatite. (c) $\mathrm{Ca} \mathrm{L}_{2,3}$-edge spectra of a reference calcite

699 and amorphous calcium carbonate, showing the method for the calculation of splitting ratios,

700 quantifying calcium carbonate crystallinity (see Politi et al., 2008).

701

702 

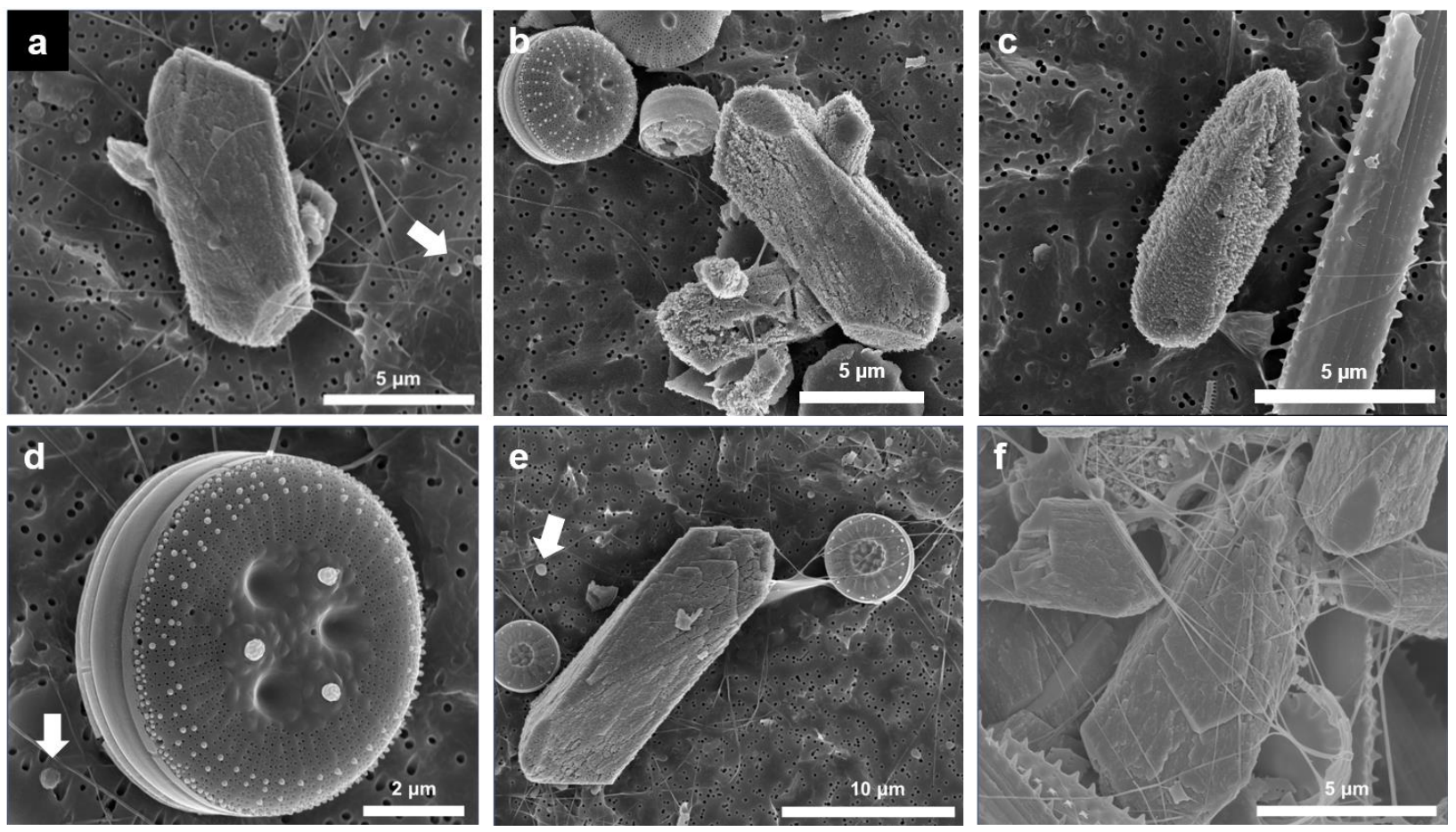

704 Figure 2. SEM images of whiting particles from the FGL water column. (a) Smooth-surfaced

705 calcium carbonate mineral interlaid with organic fibrils, characteristic of peak whiting ( $3 \mathrm{~m} \mathrm{depth,}$

706 June). (b) Pitted calcium carbonate grains and centric diatoms (8 m depth, August). (c) Increasingly

707 pitted and rounded carbonate grain, along a with pennate diatom (8 m depth, September 8). (d) A

708 centric diatom with organic material (EPS) extruding from the valve pores (3 m depth, June 30).

709 The brightness of the extruding material is indicative of heavy elements associated with the EPS

710 (possibly adsorbed ions). (e) A centric diatom, attached to a carbonate mineral grain with organic

711 fibrils (3 m depth, June). (e) Sediment trap whiting material (July 2017, $13 \mathrm{~m}$ depth) showing

712 carbonate minerals within a dense mesh of organic fibrils. White arrows in (a), (d), and (e) point

713 to possible microbial cells (Synechococcus). 


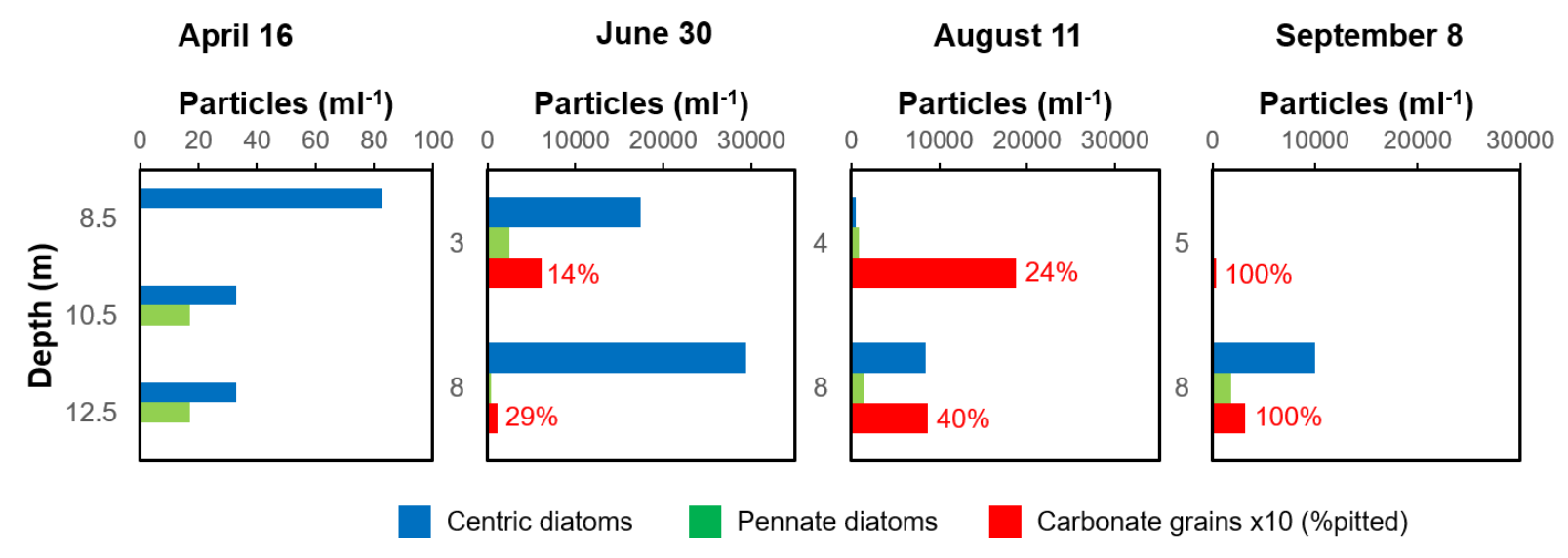

715 Figure 3. Particle types and abundances at different depths in the water column of FGL before

716 and throughout the whiting season, as counted from SEM images. Note that abundances of

717 carbonate grains have been divided by ten, and that sample collection depth vary for different

718 sampling times. The percentage of pitted carbonate particles (relative to smooth grains) is

719 indicated (brackets).

720 


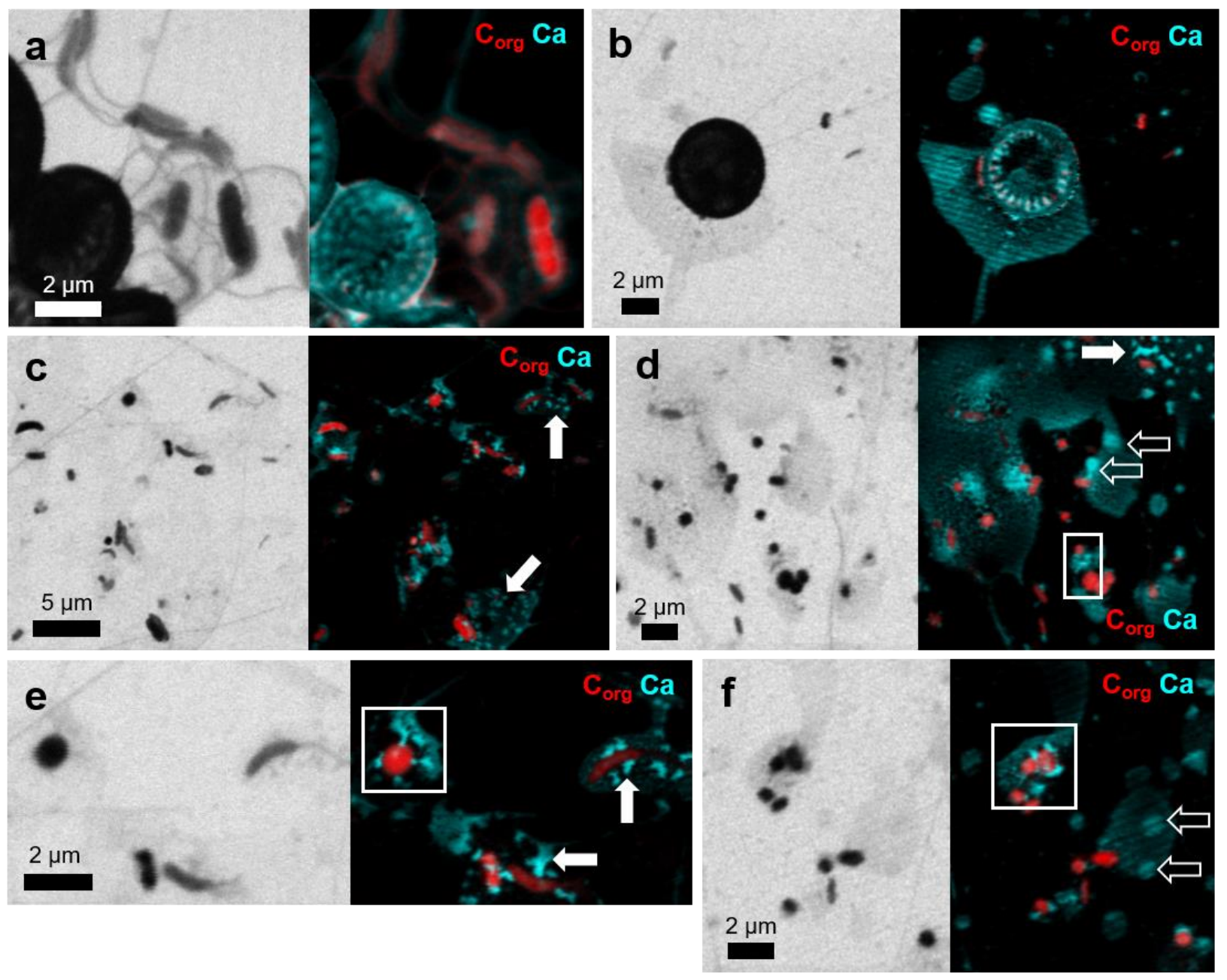

722 Figure 4. STXM analyses of pre-whiting particles from the FGL water column (April, $8 \mathrm{~m}$

723 depth). Images (left) were acquired at $288.2 \mathrm{eV}$. The corresponding maps (right) show the

724 distribution of organic carbon (red) and calcium (cyan). Whites squares show the locations of the

725 image stacks displayed in Fig. S3 and Fig. 7. White arrows show the location of irregularly

726 shaped calcium-rich clots within EPS films (identified as ACC minerals), while open arrows

727 show micron-scale, round calcium enrichments that may correspond to $\mathrm{Ca}^{2+}$ adsorbed on empty

728 EPS envelopes of Synechococcus cells. Note that EPS films and fibrils visible on STXM images

729 do not appear on organic carbon maps, which may be due to excessive thinness (see main text). 


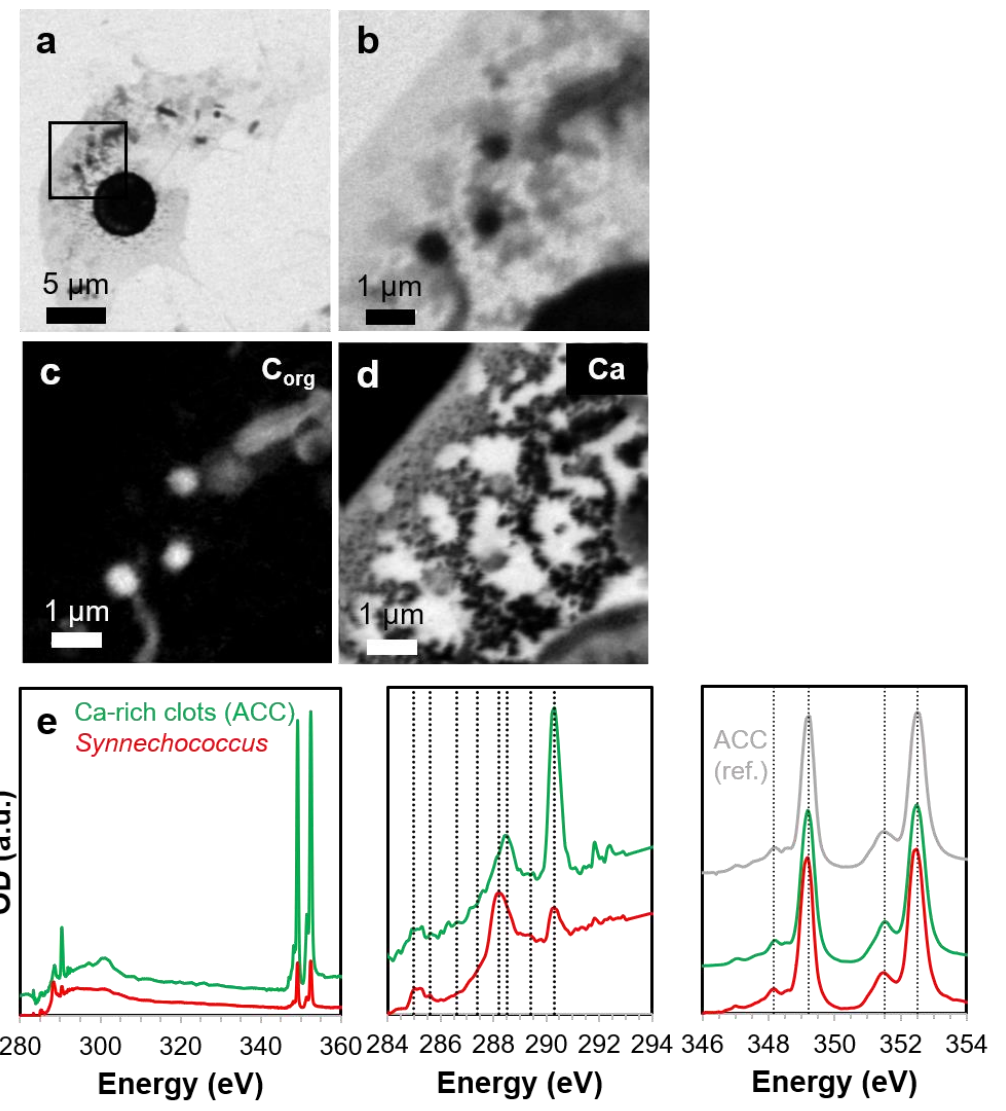

732 Figure 5. STXM analyses of diatom EPS and Synechococcus cells from a FGL pre-whiting

733 sample (April, $8 \mathrm{~m}$ depth). (a) Image obtained at $288.2 \mathrm{eV}$. A centric diatom, surrounded by EPS

734 film, is visible. (b) Close-up on the area depicted by a square in (a). Synechococcus cells are

735 present within the EPS film. (c) Organic carbon map. (d) Calcium map. (e) XANES spectra

736 representative of calcium-rich clots within the EPS film (green) and Synechococcus cells (red). C

737 K-edge spectra (middle panel): vertical lines correspond to the absorption energies of different

738 functional groups (see main text). $\mathrm{Ca} \mathrm{L}_{2,3}$-edge spectra (right panel): vertical lines correspond to

739 the position of the main peaks in the reference amorphous calcium carbonate (ACC) spectrum

740 (grey). The calcium-rich clots are identified as calcium-carbonate phases based on the presence

741 of strong X-ray absorption at $290.3 \mathrm{eV}$ and $301.5 \mathrm{eV}$. Their calculated splitting ratios are $\mathrm{SRL}_{3} \sim$

7421.2 and $\mathrm{SRL}_{2} \sim 1.3$, corresponding to $\mathrm{ACC}$. 


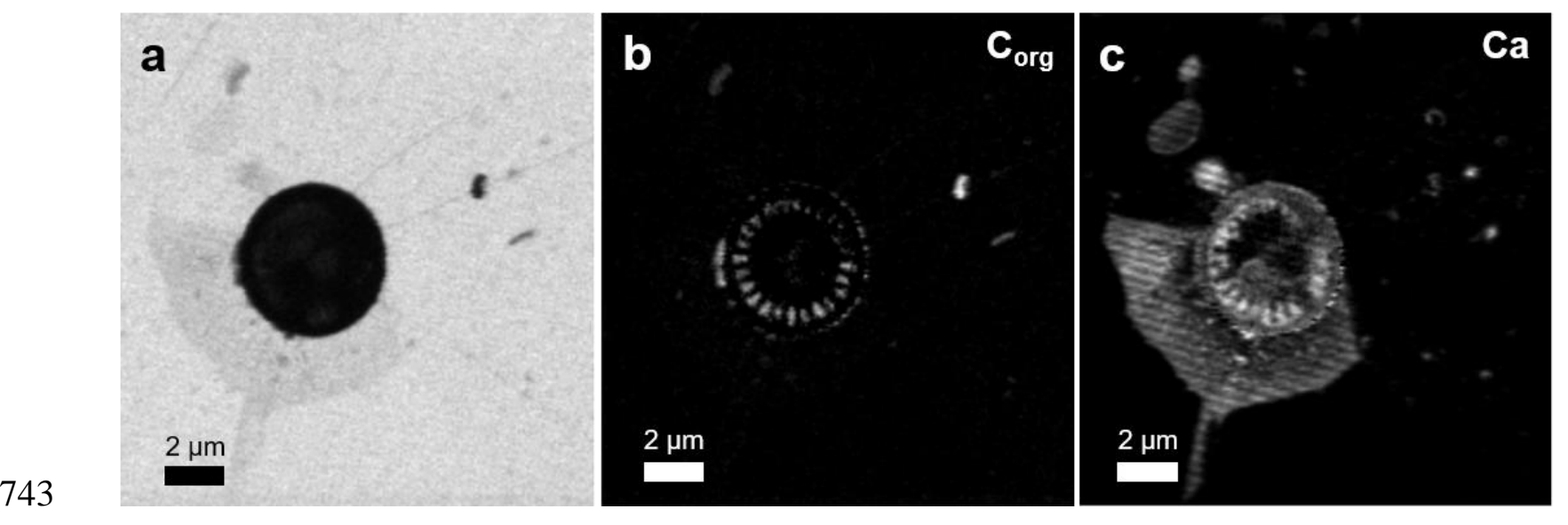

744 Figure 6. STXM image and maps of a centric diatom and associated EPS in a FGL pre-whiting

745 sample (April, $8 \mathrm{~m}$ depth). (a) Image at $288.2 \mathrm{eV}$. (b) Organic carbon map. (c) Calcium map.

746 Calcium is particularly enriched on the EPS material around the diatom, and on the perforations

747 of the frustule (from which EPS are typically exuded).

748

749 

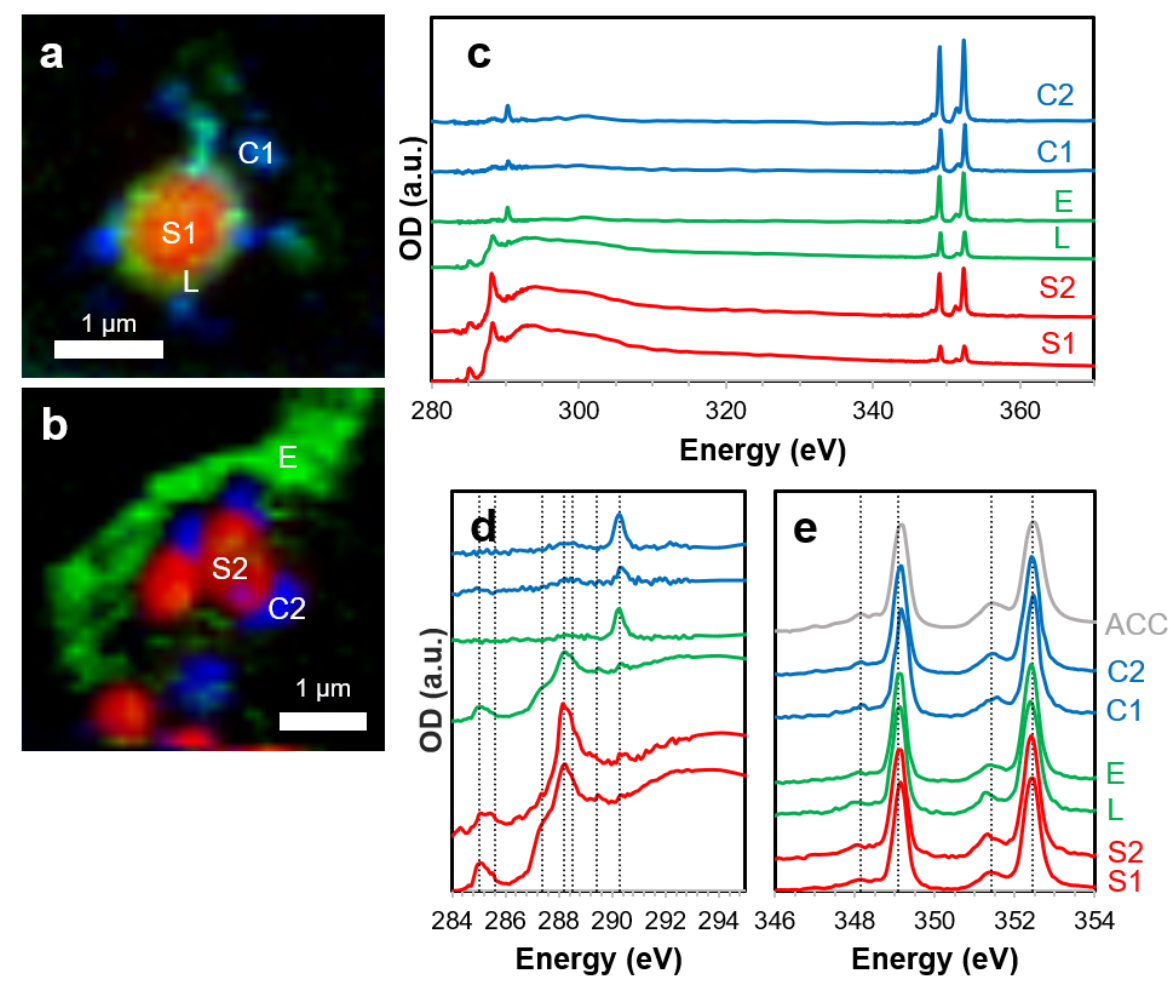

751 Figure 7. STXM analyses of Synechococcus cells, EPS and calcium-rich grains in a FGL pre-

752 whiting sample (April, $8 \mathrm{~m}$ depth). (a) and (b): maps showing the distribution of different

753 components extracted from image stacks. S1, S2: Synechococcus cells; L: outer layer of a cell; E:

754 EPS; C1,C2: calcium-rich grains. (c) Corresponding XANES spectra spanning the C K- and Ca

755 L2,3-edges. (d) C K-edge XANES spectra normalized at $320 \mathrm{eV}$. Vertical lines correspond to

756 energy positions of the main absorption features of different function groups (see main text). (e)

$757 \mathrm{Ca} \mathrm{L}_{2,3}$-edge spectra, normalized at $349.2 \mathrm{eV}$ (energy of the $\mathrm{Ca}_{3}$ peak). Vertical lines

758 correspond to the energy positions of the main absorption features of amorphous calcium

759 carbonate (ACC). Both the calcium-rich grains and EPS have spectroscopic signatures consistent

760 with ACC, showing that ACC is nucleating at the surface of Synechococcus cells, and as nano-

761 phases on EPS. 

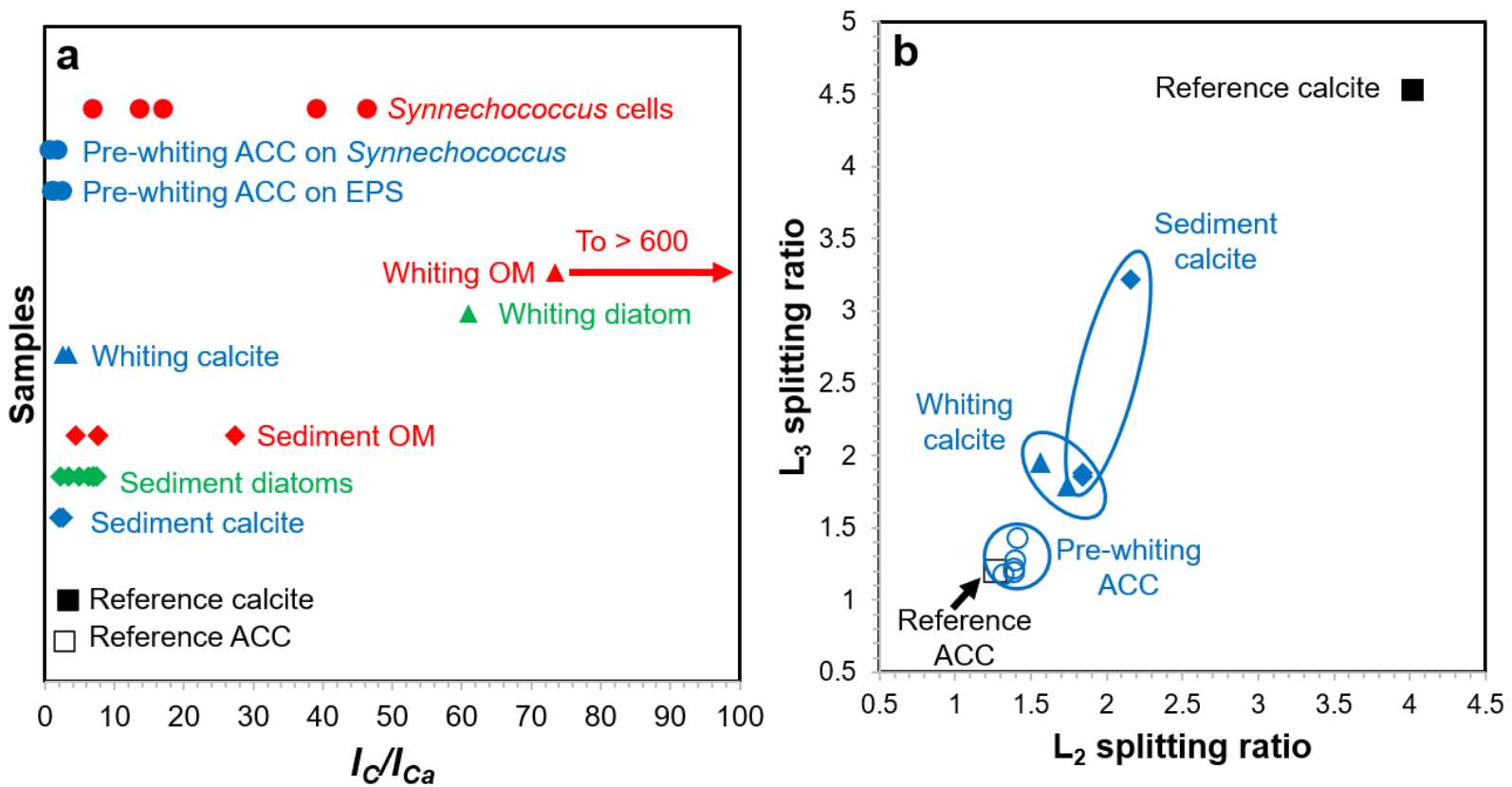

764 Figure 8. $I_{C} / I_{C a}$ ratios and splitting ratios $\left(\mathrm{SRL}_{3}, \mathrm{SRL}_{2}\right)$ for different types of samples from the

765 FGL water column and sediment. Ratios calculated from reference spectra for calcite and

766 amorphous calcium carbonate (ACC) are also plotted for comparison. (a) $I_{C} / I_{C a}$ ratios: Pre-

767 whiting Synechococcus cells and ACC correspond to the water column sample collected in April

768 at $8 \mathrm{~m}$ depth. Whiting calcite, diatoms, and organic matter (OM) correspond to sediment trap

769 samples (July, $13.5 \mathrm{~m}$ depth). Note that sediment trap OM $I_{C} / I_{C a}$ values range from $\sim 73$ to $>600$

770 (off chart). Sediment calcite, diatoms and OM correspond to sediment core samples. (b) SRL 3

771 versus SRL2 plot for calcium carbonate particles from the pre-whiting water column (April, $8 \mathrm{~m}$

772 depth) (ACC), the sediment trap (whiting calcite) and the sediment core (sediment calcite). Only

773 particles with $I_{C} / I_{C a}$ ratios smaller that 3.3, identified as calcium carbonate minerals, are plotted

774 on this chart.

775

776 

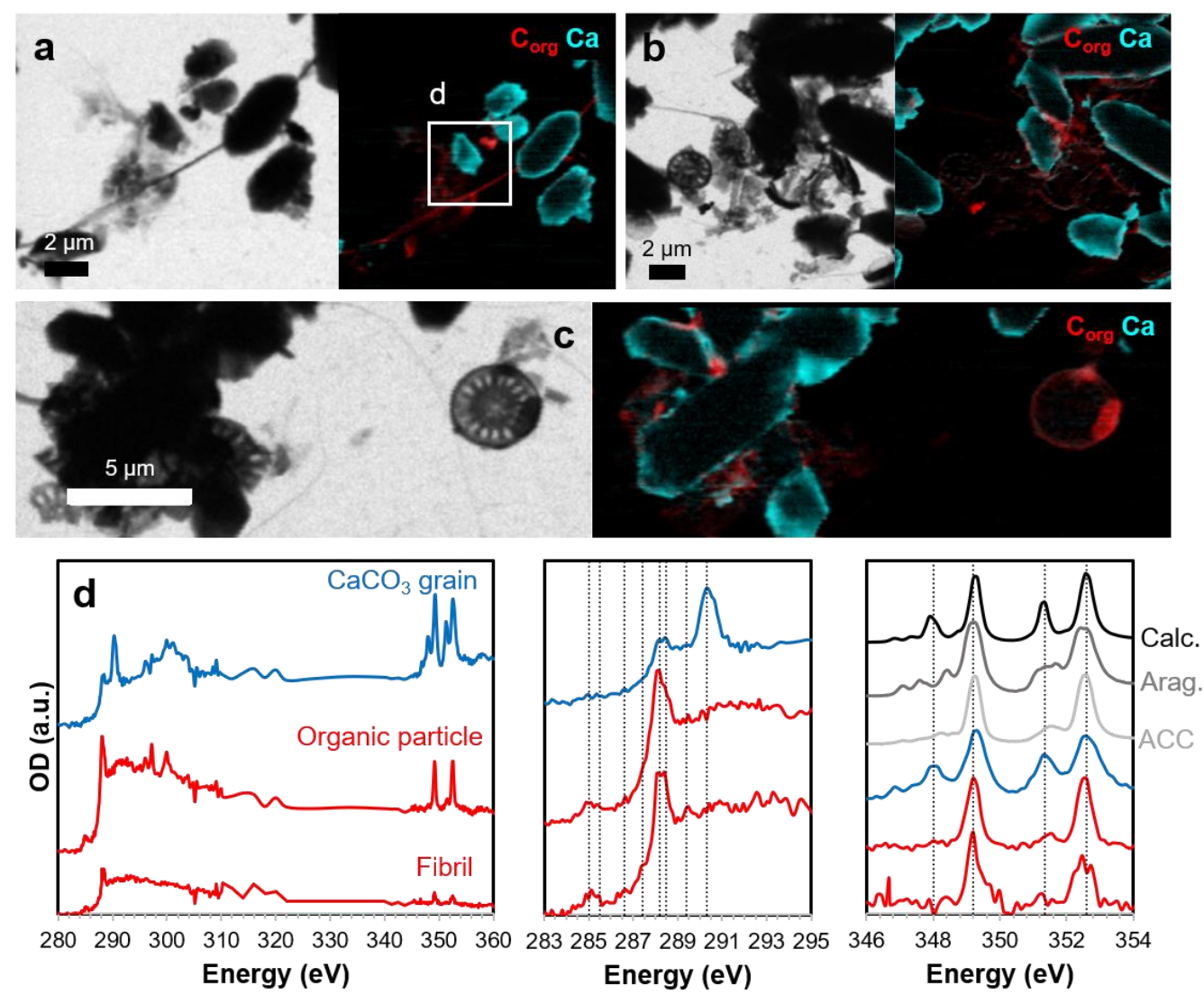

778 Figure 9. STXM analyses of settling whiting particles collected in a sediment trap (July 2017,

$77913.5 \mathrm{~m}$ depth). (a-c) Images at $288.2 \mathrm{eV}$ (left) and maps of organic carbon (red) and calcium

780 (cyan) (right). The interior of $\mathrm{CaCO}_{3}$ grains sometimes appear black on calcium maps due the

781 excessive thickness of the grains, causing saturation of the X-ray absorption signal. The white

782 box in (a) represents the location of the image stack from which spectra shown in (d) were

783 extracted. (d) XANES spectra representative of $\mathrm{a} \mathrm{CaCO}_{3}$ grain, an organic fibril, and a dense

784 organic carbon particle in (a). C K-edge spectra (middle panel): vertical lines correspond to the

785 absorption energies of different functional groups (see main text). $\mathrm{Ca}_{2,3}$-edge spectra (right

786 panel): vertical lines correspond to the position of the main peaks in a reference calcite (Calc.)

787 spectrum (black). Reference $\mathrm{Ca} \mathrm{L}_{2,3}$-edge XANES spectra for aragonite (Arag.) and amorphous

788 calcium carbonate (ACC) are also shown. 

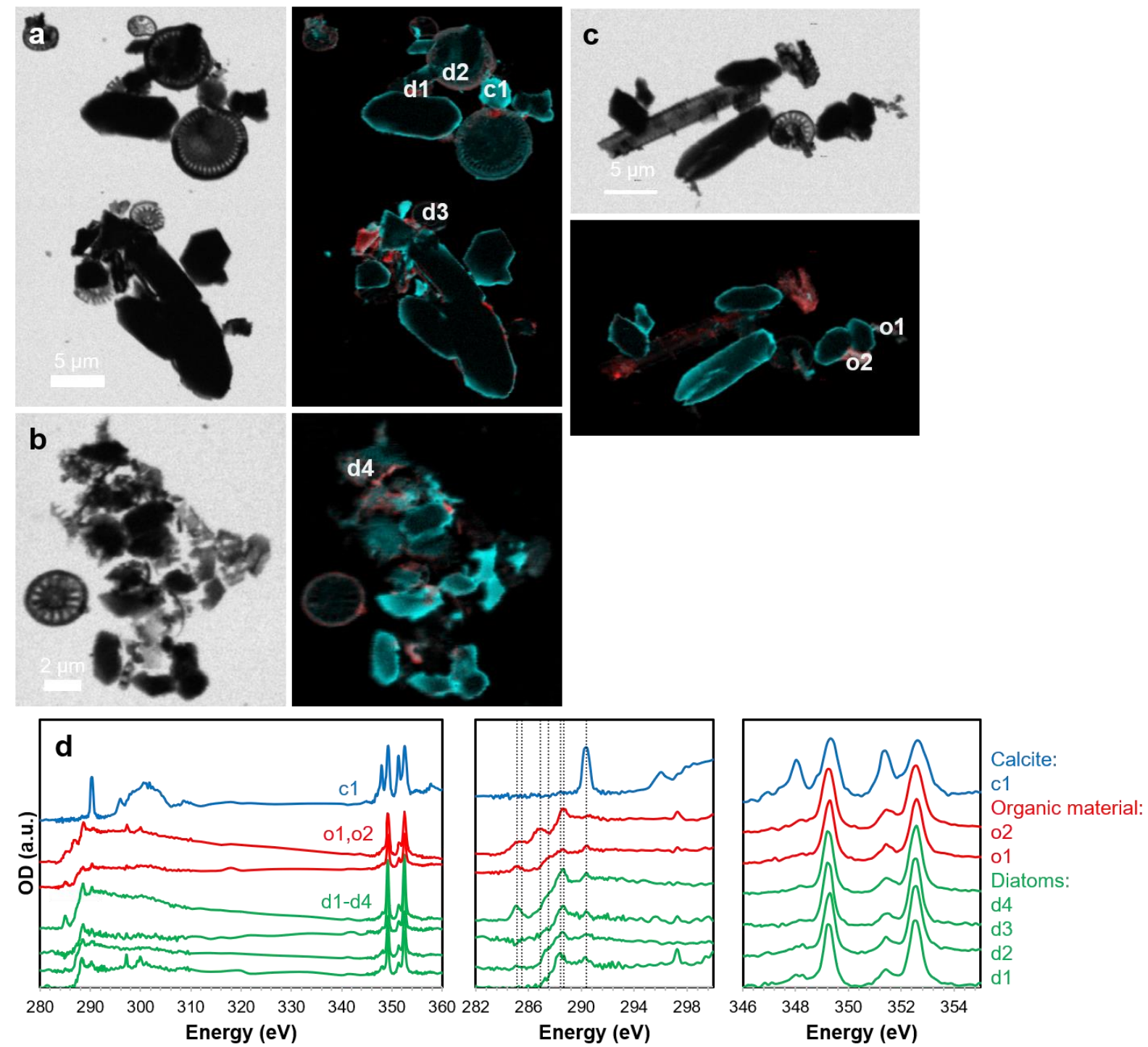

790 Figure 10. STXM analyses of particles from a FGL sediment core at 0-2 inches (a,b) and 2-4

791 inches (c) depths below the lake floor. (a-c) Images at $288.2 \mathrm{eV}$ (left) and maps of organic

792 carbon (red) and calcium (cyan) (right). The locations from which XANES spectra shown in (d)

793 were extracted are indicated: c1 (calcite grain), o1-o2 (organic material) and d1-d4 (diatoms). (d)

794 Corresponding XANES spectra. C K-edge spectra (middle panel): vertical lines correspond to

795 the absorption energies of different functional groups (see main text). Right panel: Ca L2,3-edge

796 spectra. 
A re-examination of the mechanism of whiting events: A new role for diatoms in

800

Fayetteville Green Lake (New York, USA)

801

802 

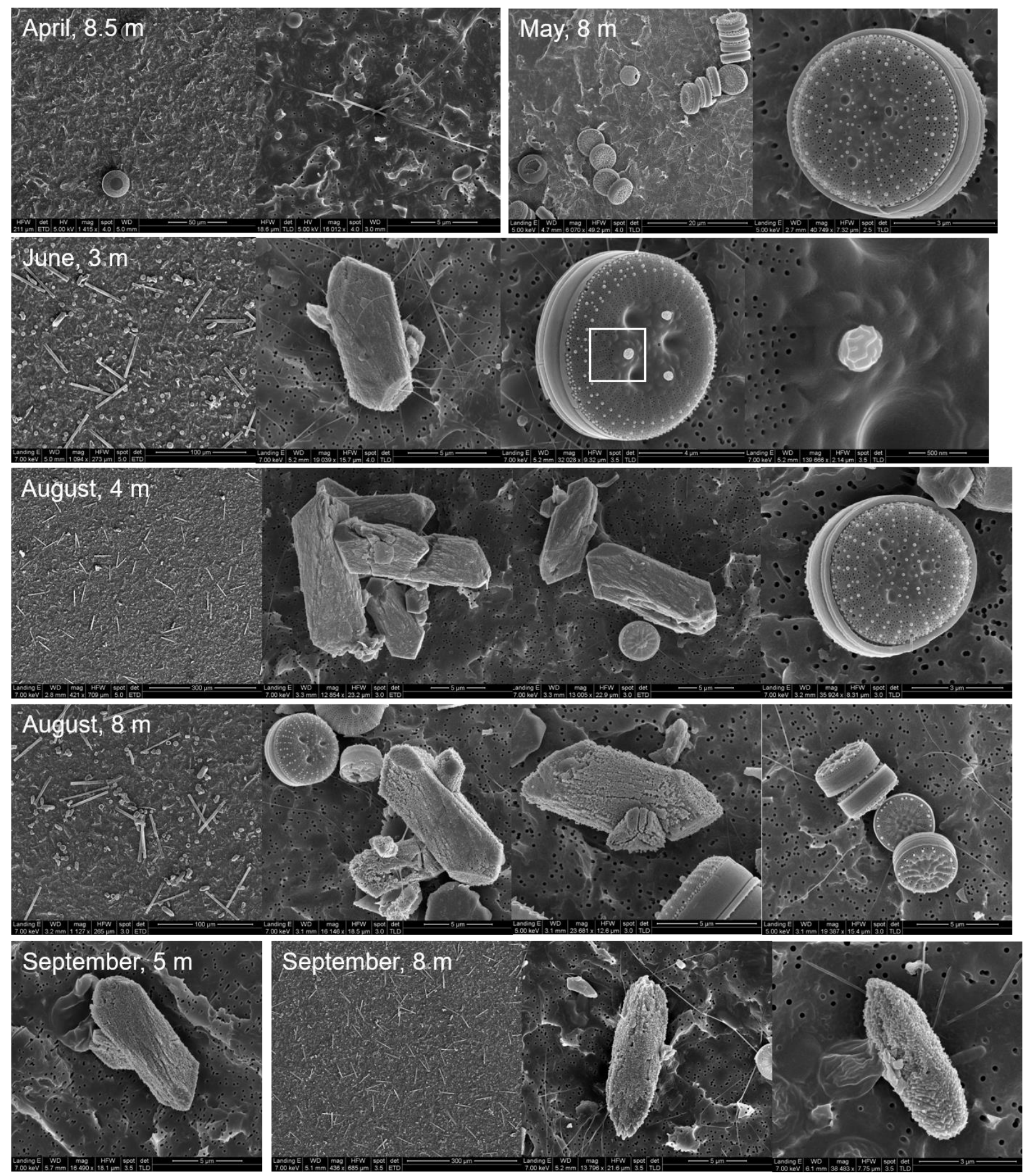

804 Figure S1. SEM images of FGL water column particulate samples collected on filters throughout

805 the 2018 whiting season. Collection times (months) and depths are indicated. 


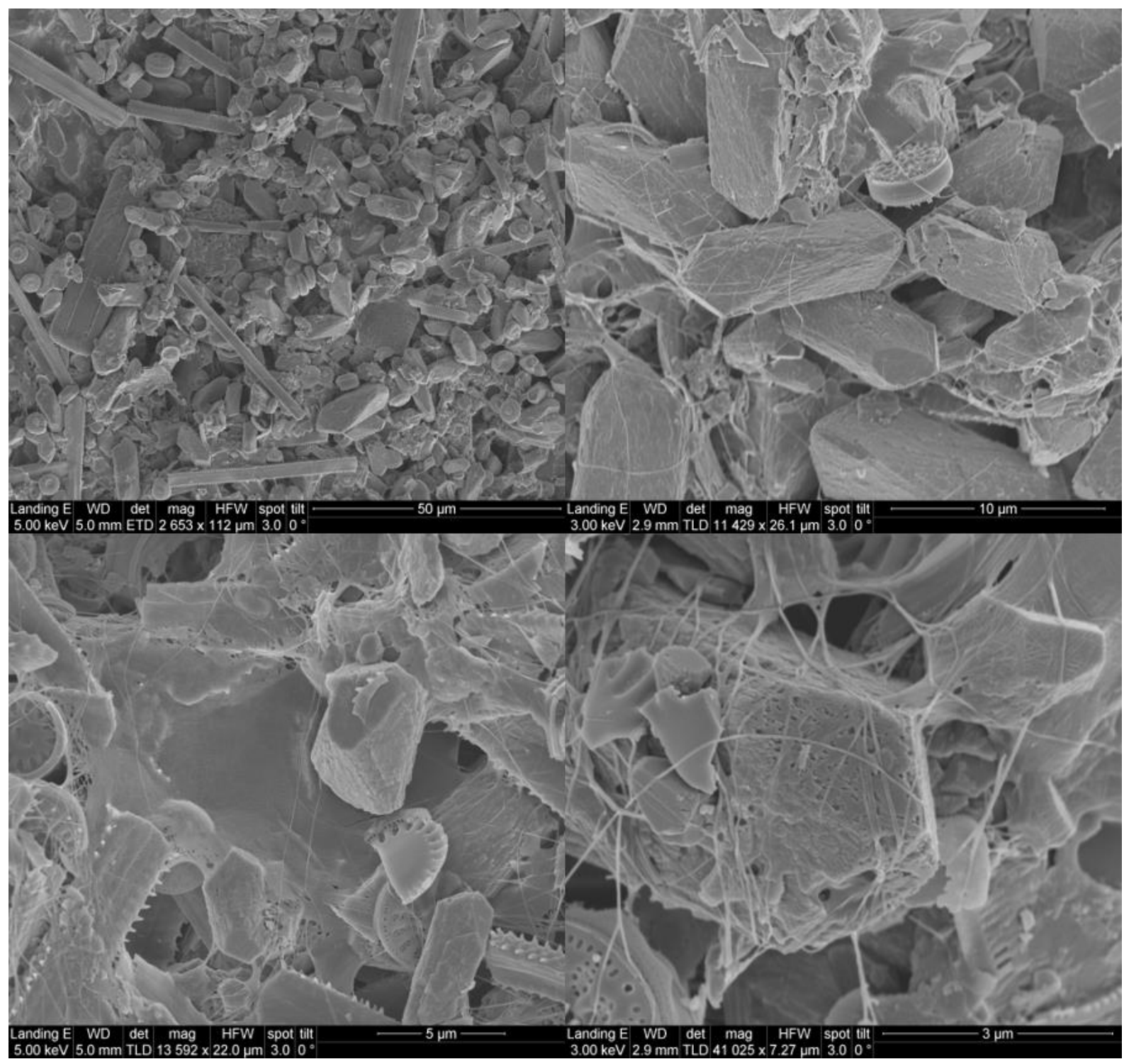

808 Figure S2. SEM images of FGL whiting particles collected in a sediment trap (July 2017, $13.5 \mathrm{~m}$ 809 depth). 

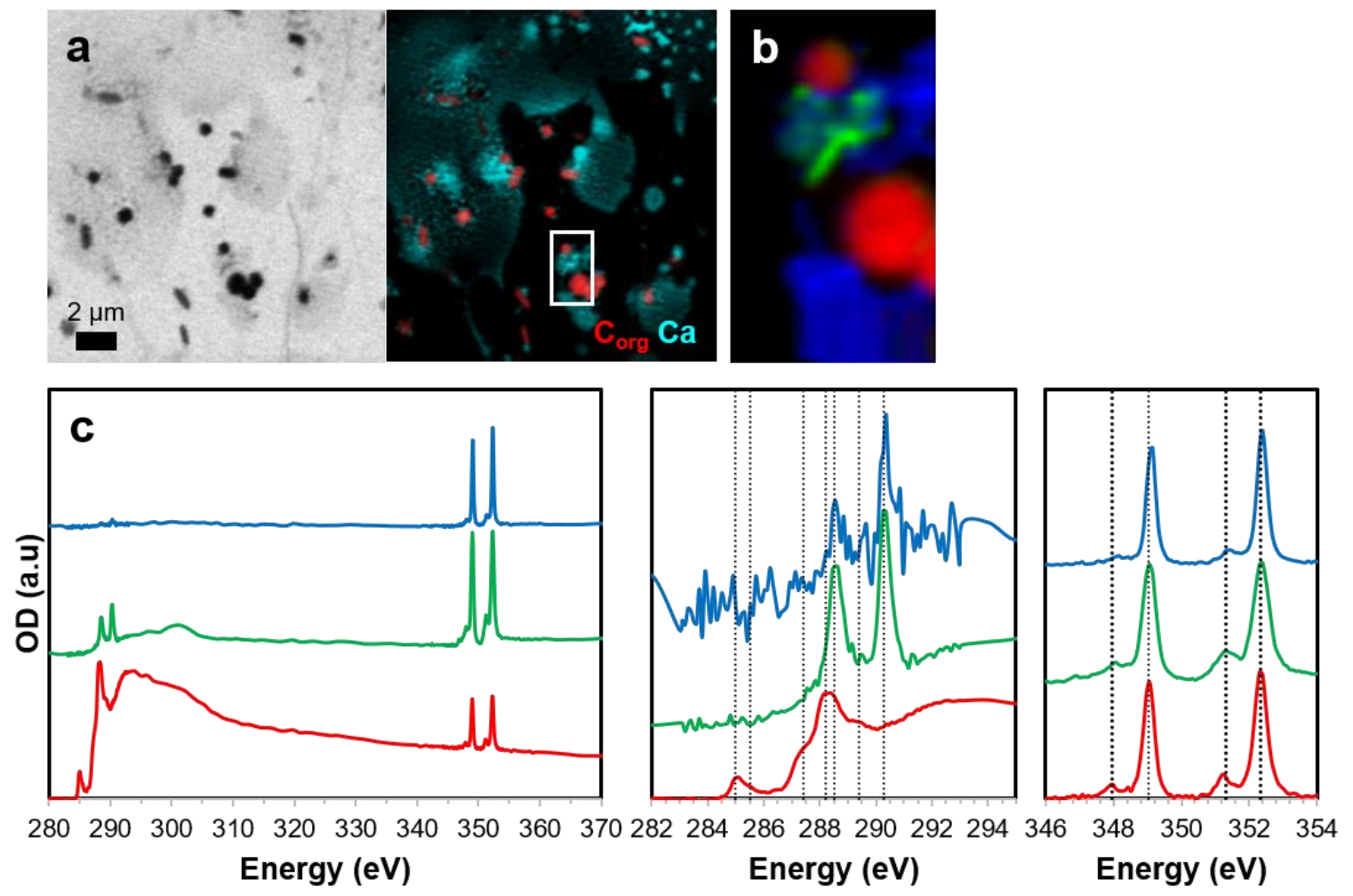

811 Energy (eV)

812 Figure S3. STXM analyses of pre-whiting particulate material from the FGL water column (April,

$8138 \mathrm{~m}$ depth). (a) Image obtained at $288.2 \mathrm{eV}$ and corresponding map showing the distribution of

814 organic carbon (red) and calcium (cyan). (b) Map obtained on the area depicted by a rectangle in 815 (a), showing a Synnechococcus cell in red, EPS in blue, and ACC particles (green). (c) XANES

816 spectra representative of the Synnechococcus cell (in red), EPS (in blue) and ACC particles (in

817 green). C K-edge spectra (middle panel): vertical lines correspond to the absorption energies of 818 different organic functional groups (see main text) and carbonate groups (at $290.3 \mathrm{eV}$ ). Ca $\mathrm{L}_{2,3-}$ 819 edge spectra (right panel): vertical lines correspond to the position of the main peaks in amorphous 820 calcium carbonate. XANES spectra acquired on the EPS (blue spectra) show the presence of 821 adsorbed $\mathrm{Ca}^{2+}$ but very weak carbonate signal, while strong carbonate and calcium peaks in the 822 green spectra indicate the presence of calcium carbonate grains, identified as ACC based on 823 splitting ratios $\left(\mathrm{SRL}_{3} \sim 1.2, \mathrm{SRL}_{2} \sim 1.4\right)$. 

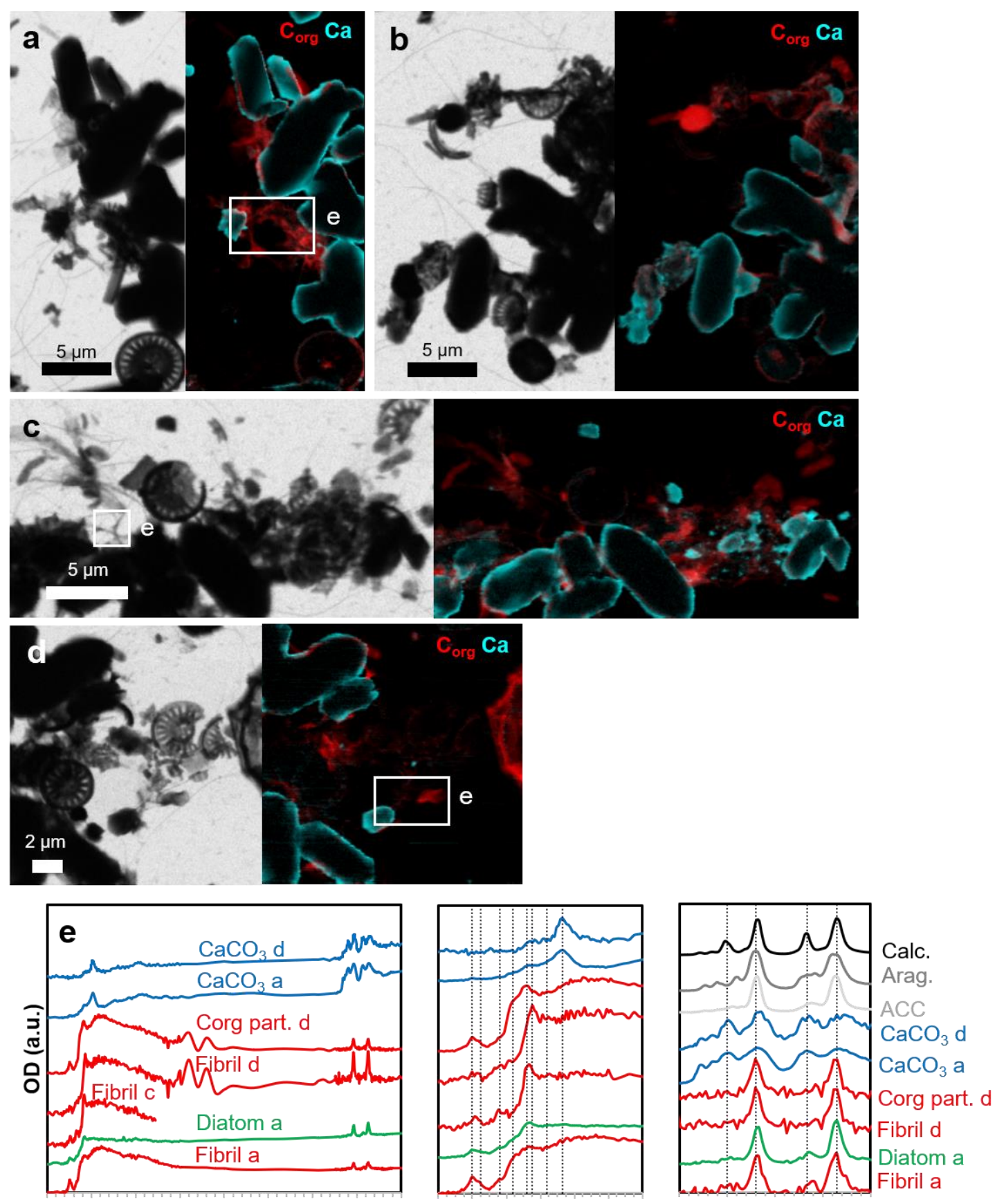

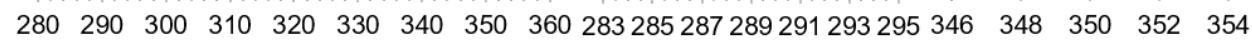

Energy (eV)

Energy (eV)

Energy (eV)

Figure S4. STXM analyses of settling whiting particles collected in a sediment trap

826 (July, $13.5 \mathrm{~m}$ depth). (a-d) Images at $288.2 \mathrm{eV}$ (left) and maps of organic carbon (red) and

827 calcium (cyan) (right). The interior of $\mathrm{CaCO}_{3}$ grains sometimes appear black on calcium maps 
828 due the excessive thickness of the grains, causing saturation of the X-ray absorption signal. The 829 white boxes represent the locations of the image stacks from which spectra shown in (e) were 830 extracted. (e) XANES spectra representative of $\mathrm{CaCO}_{3}$ grains in (a) and (d), a dense organic 831 carbon particle in (d), organic fibrils in (a), (c) and (d), and a diatom in (a). Note that for the

832 fibril in (c), the XANES spectrum was only acquired at the C K-edge. C K-edge spectra (middle 833 panel): vertical lines correspond to the absorption energies of different functional groups (see 834 main text). $\mathrm{Ca}_{2,3}$-edge spectra (right panel): vertical lines correspond to the position of the 835 main peaks in the reference calcite (Calc.) spectrum (black). Reference $\mathrm{Ca}_{2,3}$-edge XANES 836 spectra for aragonite (Arag.) and amorphous calcium carbonate (ACC) are also shown. 

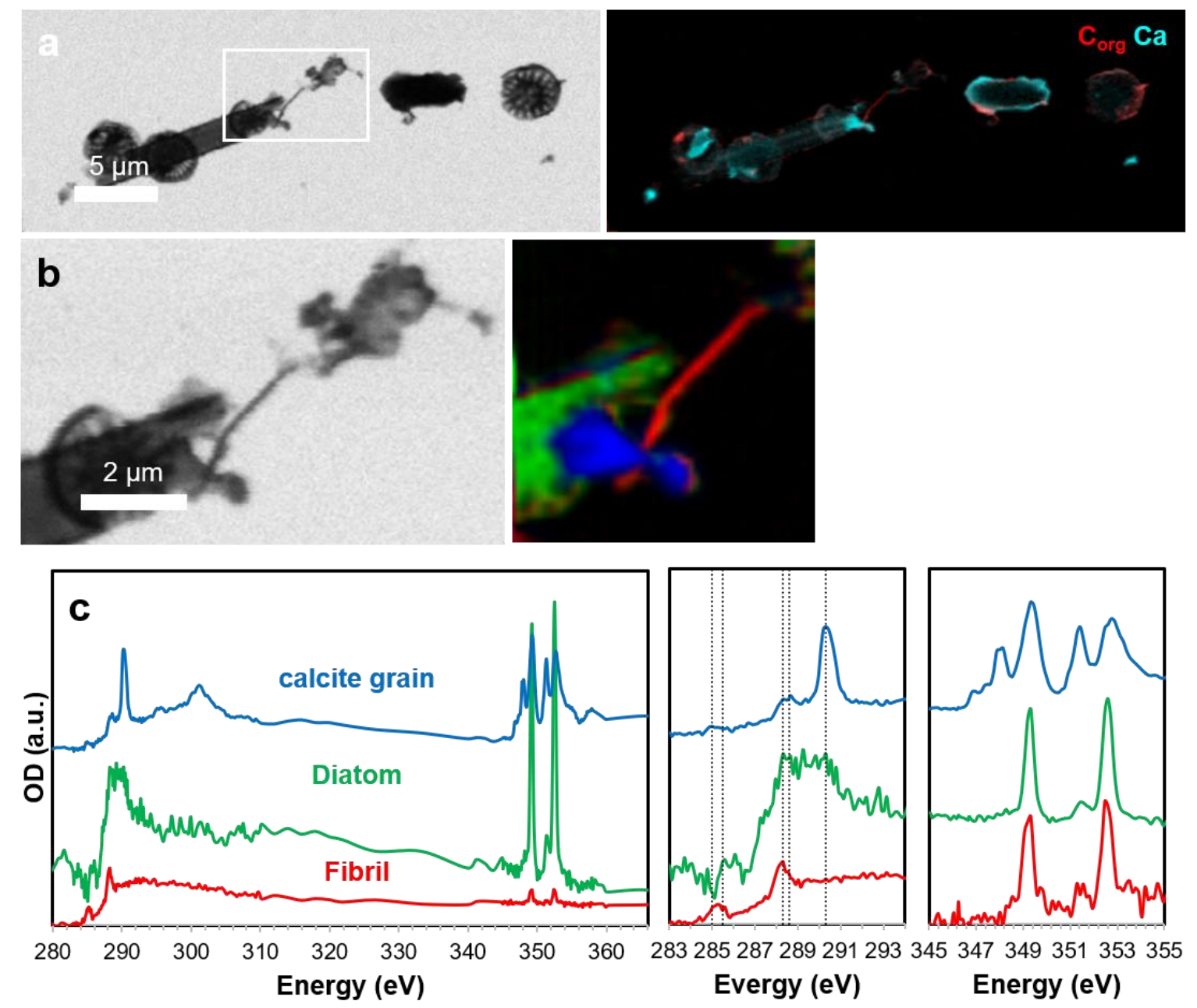

Figure S5. STXM analyses of particles from a FGL sediment core (0-2 inches). (a)

840 Image at $288.2 \mathrm{eV}$ (left) and maps of organic carbon (red) and calcium (cyan) (right). (b) Close-

841 up on the area depicted by a white box in (a). Left: image at $288.2 \mathrm{eV}$. Right: map showing the

842 distribution of different components extracted from an image stack: a calcite grain (blue), a

843 pennate diatom (green), and an organic filament (red). (c) Corresponding XANES spectra. The

844 vertical lines in the $\mathrm{C}$ K-edge spectrum (middle panel) correspond to energy positions of the

845 main absorption features of different function groups (see main text). 

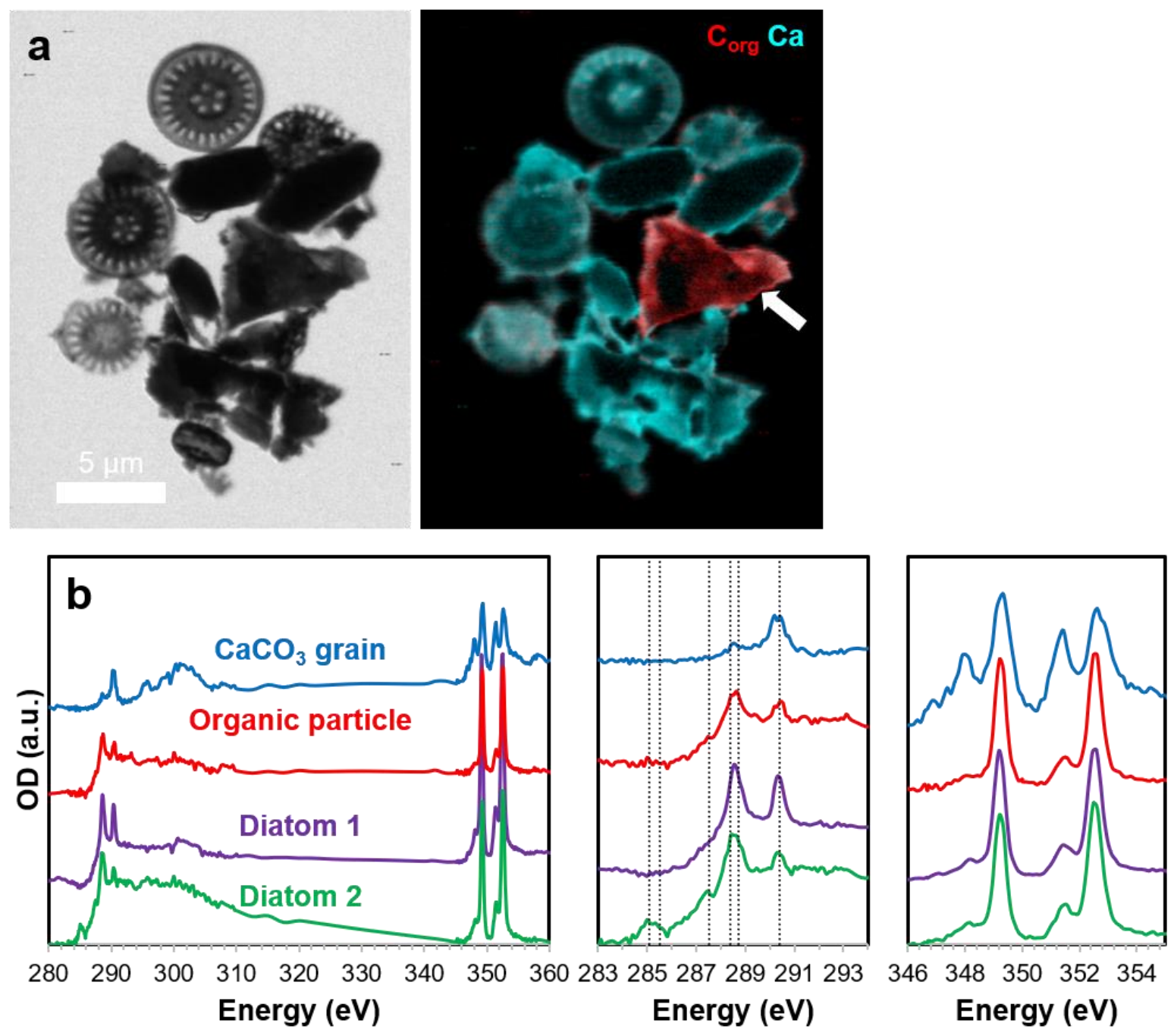

Figure S6. STXM analyses of particles from a FGL sediment core (2-4 inches). (a)

848 Image at $288.2 \mathrm{eV}$ (left) and maps of organic carbon (red) and calcium (cyan) (right). The white

849 arrow points to a dense organic-rich particle. (b) XANES spectra representative of different types

850 of objects in (a): a calcite grain, an organic particle, and two different diatoms. The vertical lines

851 in the $\mathrm{C}$ K-edge spectrum (middle panel) correspond to energy positions of the main absorption

852 features of different function groups (see main text). 